\title{
Cannabidiol, a non-psychoactive cannabinoid, leads to EGR2-dependent anergy in activated encephalitogenic T cells
}

Ewa Kozela ${ }^{1 *}$, Ana Juknat ${ }^{1}$, Nathali Kaushansky ${ }^{2}$, Avraham Ben-Nun ${ }^{3}$, Giovanni Coppola ${ }^{4}$ and Zvi Vogel ${ }^{1,2}$

\begin{abstract}
Background: Cannabidiol (CBD), the main non-psychoactive cannabinoid, has been previously shown by us to ameliorate clinical symptoms and to decrease inflammation in myelin oligodendrocyte glycoprotein (MOG)35-55-induced mouse experimental autoimmune encephalomyelitis model of multiple sclerosis as well as to decrease MOG35-55-induced T cell proliferation and IL-17 secretion. However, the mechanisms of CBD anti-inflammatory activities are unclear.

Methods: Here we analyzed the effects of CBD on splenocytes (source of accessory T cells and antigen presenting cells (APC)) co-cultured with MOG35-55-specific T cells ( $T_{\text {MOG }}$ ) and stimulated with MOG35-55. Using flow cytometry, we evaluated the expression of surface activation markers and inhibitory molecules on $T$ cells and B cells. $T_{\text {MOG }}$ cells were purified using CD4 positive microbead selection and submitted for quantitative PCR and microarray of mRNA transcript analyzes. Cell signaling studies in purified $T_{\text {MOG }}$ were carried out using immunoblotting.
\end{abstract}

Results: We found that CBD leads to upregulation of CD69 and lymphocyte-activation gene 3 (LAG3) regulatory molecules on $\mathrm{CD}^{+} \mathrm{CD} 25^{-}$accessory $T$ cells. This subtype of $\mathrm{CD} 4^{+} \mathrm{CD} 25^{-} \mathrm{CD} 69^{+} \mathrm{LAG} 3^{+} \mathrm{T}$ cells has been recognized as induced regulatory phenotype promoting anergy in activated $T$ cells. Indeed, we observed that CBD treatment results in upregulation of EGR2 (a key T cell anergy inducer) mRNA transcription in stimulated $\mathrm{T}_{\text {MOG }}$ cells. This was accompanied by elevated levels of anergy promoting genes such as IL-10 (anti-inflammatory cytokine), STAT5 (regulatory factor), and LAG3 mRNAs, as well as of several enhancers of cell cycle arrest (such as Nfatc1, Casp4, Cdkn1a, and ICos). Moreover, CBD exposure leads to a decrease in STAT3 and to an increase in STAT5 phosphorylation in $\mathrm{T}_{\text {MOG }}$ cells, positive and negative regulators of Th17 activity, respectively. In parallel, we observed decreased levels of major histocompatibility complex class II (MHCII), CD25, and $\mathrm{CD} 69$ on $\mathrm{CD} 19^{+} \mathrm{B}$ cells following CBD treatment, showing diminished antigen presenting capabilities of B cells and reduction in their pro-inflammatory functions.

Conclusions: Our data suggests that $\mathrm{CBD}$ exerts its immunoregulatory effects via induction of $\mathrm{CD} 4^{+} \mathrm{CD} 25^{-} \mathrm{CD} 69^{+} \mathrm{LAG} 3^{+}$ cells in MOG35-55-activated APC/ $T_{\text {MOG }}$ CO-cultures. This is accompanied by EGR2-dependent anergy of stimulated $T_{\text {MOG }}$ cells as well as a switch in their intracellular STAT3/STAT5 activation balance leading to the previously observed decrease in Th17 activity.

Keywords: Cannabidiol, Memory T cells, LAG3, CD69, EGR2, T cell anergy

\footnotetext{
* Correspondence: ewa.kozela@weizmann.ac.il

${ }^{1}$ The Dr Miriam and Sheldon G. Adelson Center for the Biology of Addictive Diseases, Sackler Faculty of Medicine, Tel Aviv University, Tel Aviv, Israel Full list of author information is available at the end of the article
} 


\section{Background}

Cannabinoids, the active materials found in Cannabis preparations (for example, in marijuana), have been shown to exert potent immunomodulatory and anti-inflammatory activities in various animal models of diseases with inflammatory background, including rheumatoid arthritis, experimental colitis, liver inflammation, brain injury, neurodegeneration, and multiple sclerosis (MS) (reviewed by $[1,2])$. MS is a neurodegenerative inflammatory disease of unknown trigger and complex neuroimmune pathology that involves myelin degeneration and CNS dysfunction. Encephalitogenic $\mathrm{T}$ cells specific for myelin components (primed by antigen presenting cells (APC)) have a key role in MS pathology $[3,4]$ as well as in the mouse experimental autoimmune encephalomyelitis (EAE) model of MS [5]. We and others have shown that several cannabinoids including the main psychoactive $\Delta$-9-tetrahydrocannabinol (THC) [6,7] and the main non-psychoactive cannabinoid, cannabidiol (CBD) [8] ameliorate CNS neuroinflammation and demyelination in EAE. Moreover, we have shown recently that $\mathrm{CBD}$ and $\mathrm{THC}$ decrease the myelin oligodendrocyte glycoprotein (MOG)35-55-induced $\mathrm{T}$ cell proliferation as well as the secretion of IL-17 and IL-6 cytokines [9], the key autoimmune cytokines that define the Th17 pathogenic phenotype [10,11]. Moreover, $\mathrm{CBD}$ increases the production of the anti-inflammatory IL10 cytokine in these MOG35-55-stimulated T cells [9].

$\mathrm{T}$ cell effector functions and tolerance are controlled through multiple signaling pathways regulated by interactions with APC (and other accessory immune cells) and their surface molecules. Among the molecules shown to regulate memory $\mathrm{T}$ cell function, lymphocyte-activation gene 3 (LAG3; CD223) and CD69 have gained a major interest. LAG3 is a CD4 homolog that by interfering with major histocompatibility complex class II (MHCII) on APC upon antigen exposure [12] inhibits the function and expansion of memory T cells [13-15]. Furthermore, LAG3 upregulation induces early growth response 2 (EGR2)dependent anergy (exhaustion) of activated T cells, this way limiting their pathogenic activity $[16,17]$. CD69 is a very potent inhibitory co-receptor that was found to serve as a constitutive suppressor of Th17 differentiation $[18,19]$. LAG3 and CD69 were reported to be induced on certain populations of $\mathrm{CD} 4^{+} \mathrm{CD} 25^{-} \mathrm{T}$ cells $[20,21]$ but were scarcely observed on the cell surface of $\mathrm{CD} 4{ }^{+} \mathrm{CD} 25^{+}$cells that serve as naturally occurring regulatory $\mathrm{T}$ cells (nTreg) [22]. Indeed, $\mathrm{CD} 4^{+} \mathrm{CD} 25^{-} \mathrm{T}$ cells have been recently characterized as the main source of inducible non-conventional regulatory $\mathrm{T}$ cells $[23,24]$ exerting their suppressive activity via a number of suppressory molecules including LAG3, CD69, IL10 , and TGF $\beta$, and by this way promoting exhaustion of pathogenic $\mathrm{T}$ cells, mainly through EGR2-driven mechanisms $[19,21,24,25]$.
There is almost no data describing the role of regulatory cell phenotypes and/or inhibitory co-receptors in the anti-inflammatory effects of cannabinoids. Therefore, we addressed this question using an in vitro system that employs interaction of encephalitogenic, MOG35-55 specific $T$ cells $\left(\mathrm{T}_{\mathrm{MOG}}\right.$ ) with peripheral spleen-derived $\mathrm{APC}$ and naïve accessory $\mathrm{T}$ cells.

Antigen presentation to memory/encephalitogenic T cells is known to lead to activation of several cell cycle and effector pathways including the phosphatidylinositol-3-kinase/ Akt/mTOR pathway, the mitogen-activated protein kinase (MAPK) pathway, and the Janus kinase/Signal transducers and Activators of Transcription (JAK/STATs) pathway [26,27]. Although Akt and MAPK pathways have been shown to be targeted by cannabinoids in various immune and non-immune cells $[2,28]$, there is almost no data regarding the effect of cannabinoids on the activity of these pathways in inflammatory and autoimmune conditions. In this regard, we have recently shown that CBD exerts its anti-inflammatory activity in activated microglial cells via regulation of STAT1/STAT3 balance $[29,30]$ demonstrating that STAT family members are targeted by CBD. STAT3 has been described as a key positive regulator of Th17 proliferation and function, including upstream regulation of RORyt-dependent production of IL-17 [31]. STAT5 is a major immunoregulatory factor restraining STAT3 proTh17 activity [32]. The ratio between STAT3 and STAT5 has been proposed to serve as a key factor determining the final pathogenic activity of autoreactive Th17 cells and its anergic propensity [33]. Moreover, EGR2 has been shown to act as an essential negative STAT3 regulator including IL-17 expression and Th17 expansion [34].

Herein, using an in vitro model of stimulated $\mathrm{T}_{\text {MOG }}$ cells co-cultured with spleen-derived $\mathrm{CD} 19^{+} \mathrm{B}$ cells serving as APC and other accessory $\mathrm{CD} 4^{+}$cells, we investigated the pathways and molecules mediating the immunoregulatory effects of CBD. The results show that CBD exerts its immunoregulatory effects via strong upregulation of CD69 and of LAG3 inhibitory molecules on $\mathrm{CD} 4{ }^{+} \mathrm{CD} 25^{-} \mathrm{T}$ cells. This is accompanied by EGR2, LAG3, and IL-10-dependent anergy of stimulated autoreactive $\mathrm{T}_{\text {MOG }}$ cells, followed by a shift in STAT3/STAT5 activation ratio leading to decreased Th17-like activity of CBD-treated memory encephalitogenic $\mathrm{T}$ cells observed by us previously.

\section{Materials and methods Reagents}

Lyophilized MOG35-55 peptide [MEVGWYRSPFSRVVHLYRNGK] purchased from GenScript (Piscataway, NJ, USA) was reconstituted in sterile PBS and the stock solution stored in aliquots at $-20^{\circ} \mathrm{C}$. $\mathrm{CBD}$ was obtained from the National Institute on Drug Abuse (Baltimore, MD, USA) and was dissolved in ethanol. The dose $5 \mu \mathrm{M}$ of 
CBD used here was selected based on our previous studies in which we showed that $\mathrm{CBD}$ at $5 \mu \mathrm{M}$ significantly inhibited MOG-35-55-induced $\mathrm{T}_{\mathrm{MOG}}$ cell proliferation and their Th17-like activity, that is, IL-17 release [8,9]. The final concentrations of ethanol in the various experiments did not exceed $0.1 \%$ and had no effect on the results. Fetal calf serum (FCS) and other tissue culture reagents were obtained from Biological Industries (Kibbutz Beit HaEmek, Israel).

\section{Encephalitogenic $T$ cell line}

The MOG35-55-specific $\mathrm{T}$ cell line $\left(\mathrm{T}_{\mathrm{MOG}}\right)$ was established from lymph node cells of C57BL/6 female mice that had been primed 10 days earlier with MOG35-55 emulsified in Complete Freund Adjuvant as previously described $[5,8]$. This $\mathrm{T}_{\mathrm{MOG}}$ cell line has been maintained in vitro in RPMI-1640 containing 5\% FCS and supplemented with recombinant human $10 \mathrm{U} / \mathrm{ml}$ of IL-2 (human/mouse crossreactive, Peprotech Inc, Rocky Hill, NJ, USA; IL-2 enables $\mathrm{T}_{\text {MOG }}$ growth and expansion in between antigen stimulations), $2 \mathrm{mM} \mathrm{L}$-glutamine, $100 \mu \mathrm{g} / \mathrm{ml}$ streptomycin, $100 \mathrm{U} /$ $\mathrm{ml}$ penicillin, $50 \mu \mathrm{M} \beta$-mercaptoethanol, non-essential amino acids, and $1 \mathrm{mM}$ sodium pyruvate (maintenance medium) with alternate stimulation with MOG35-55 $(5 \mu \mathrm{g} / \mathrm{ml})$ every 14 days as previously described $[5,8]$.

\section{Flow cytometry analysis of immune cell phenotypes}

$\mathrm{T}_{\text {MOG }}$ cells $\left(1 \times 10^{6}\right.$ cells $)$ were suspended in $4 \mathrm{ml}$ of RPMI-1640 containing 2.5\% FCS, $100 \mu \mathrm{g} / \mathrm{ml}$ streptomycin, $100 \mathrm{U} / \mathrm{ml}$ penicillin, $2 \mathrm{mM} \mathrm{L}$-glutamine, and $50 \mu \mathrm{M}$ $\beta$-mercaptoethanol (assay medium) and transferred to a 10 -cm tissue culture dish. APCs $\left(20 \times 10^{6}\right.$ cells $)$ freshly isolated from spleens of 8-week naïve male $\mathrm{C} 57 \mathrm{BL} / 6$ mice were added, and the mixture ( $\mathrm{APC} / \mathrm{T}_{\mathrm{MOG}}$ co-cultures) was stimulated with $5 \mu \mathrm{g} / \mathrm{ml}$ of MOG35-55. Non-stimulated and MOG35-55-stimulated APC/ $\mathrm{T}_{\mathrm{MOG}}$ co-cultures were incubated in $37^{\circ} \mathrm{C}$ in a $5 \% \mathrm{CO}_{2}$ incubator with or without $\mathrm{CBD}$ at $5 \mu \mathrm{M}$ for $18 \mathrm{~h}$. Then, the cells were spun down $(5 \mathrm{~min}, 800 \times g)$, the cell pellet resuspended in FACS buffer (PBS w/o Ca $\left.{ }^{++} / \mathrm{Mg}^{++}, 1 \% \mathrm{BSA}\right)$, incubated with anti-mouse CD16/CD32 mAb (clone 93; Biolegend, San Diego, CA, USA), and aliquots of $1 \times 10^{6}$ cells in $0.1 \mathrm{ml}$ were subjected to staining at $4^{\circ} \mathrm{C}$ for $30 \mathrm{~min}$ using predetermined optimal concentrations of fluorophore-conjugated antibodies (all from Biolegend) including: CD4-FITC (H219.19), CD19FITC (6D5), MHCII-PE (AF6-120.1), CD25-APC (3C7), CD69-PE (H1.2 F3), CD69-PE/Cy7 (H1.2 F3), and LAG3$\mathrm{PE}(\mathrm{C} 9 \mathrm{~B} 7 \mathrm{~W})$. Staining was followed by two- or four-color immunofluorescence analysis by flow cytometry. Isotypeand concentration-matched control antibodies were used to assess non-specific staining. The cells were examined by BD LCSII flow cytometer (Becton Dickinson, Franklin Lakes, NJ, USA) using FACSDiva software (BD).
In additional control experiments, freshly isolated splenocytes were cultured without MOG35-55 (resting splenocytes), or $\mathrm{T}_{\text {MOG }}$ cells were cultured without APC and without MOG35-55 (resting $\mathrm{T}_{\mathrm{MOG}}$ cells) for $18 \mathrm{~h}$ in the presence or absence of $5 \mu \mathrm{M} \mathrm{CBD}$ in maintenance medium. After this time, resting splenocytes or resting $\mathrm{T}_{\text {MOG }}$ cells were collected and processed by flow cytometry analysis as described above.

\section{$\mathrm{CD}^{+}$microbead purification of $\mathrm{T}_{\text {MOG }}$ cells from $\mathrm{APC} / \mathrm{T}_{\mathrm{MOG}}$ co-cultures}

Dissociated spleen cells were plated in $10-\mathrm{cm}$ plates $(50 \times$ $10^{6}$ cells/plate) in assay medium. After $2 \mathrm{~h}$ at $37^{\circ} \mathrm{C}$ in $5 \%$ $\mathrm{CO}_{2}$ humidified air to allow APC adherence, the media with non-adherent cells were removed, and the adherent APCs were gently washed with $\mathrm{Ca}^{++} / \mathrm{Mg}^{++}$containing PBS and covered with a new assay medium. Then, $2.5 \times 10^{6}$ of $\mathrm{T}_{\text {MOG }}$ cells were added and APC/ $\mathrm{T}_{\text {MOG }}$ co-cultures were stimulated immediately with $5 \mu \mathrm{g} / \mathrm{ml}$ of MOG35-55 for $8 \mathrm{~h}$ in the presence or absence of CBD at $5 \mu \mathrm{M}$. CBD was added just prior to the addition of the MOG35-55. After $8 \mathrm{~h}$ of incubation, the media containing mostly $\mathrm{T}_{\mathrm{MOG}}$ cells (but not the adherent APC cells) were carefully collected and spun down for $10 \mathrm{~min}$ at $800 \times g$. The cell pellet was washed in PBS containing 0.5\% BSA and $2 \mathrm{mM}$ EDTA, centrifuged again and resuspended in $90 \mu \mathrm{l}$ of this buffer. To improve the purity of collected cells, CD4 (L3T4) magnetic beads (Miltenyi Biotec GmbH, Bergisch Gladbach, Germany) were added to the cell suspension for positive selection of $\mathrm{CD}_{4}^{+}$cells according to the manufacturer instructions. The $\mathrm{CD}^{+}$cells obtained this way (purified $\mathrm{T}_{\text {MOG }}$ cells) were subjected to protein phosphorylation assays (by immunoblotting) and to mRNA expression studies (by qPCR and gene arrays).

The incubation time of $8 \mathrm{~h}$ and the $5 \mu \mathrm{M}$ dose of CBD were chosen based on previous time- and doseresponse experiments, including cytokine production and release [9].

\section{CBD effects on signaling pathways}

We checked the phosphorylation status of Akt, STAT3, and STAT5 using appropriate anti-phospho antibodies and Western blot analysis. The CD4 microbead purified $\mathrm{T}_{\text {MOG }}$ cells were rinsed twice with ice-cold PBS and lysed in RIPA buffer $(140 \mathrm{mM} \mathrm{NaCl}, 20 \mathrm{mM}$ Tris pH 7.4, 10\% glycerol, $1 \%$ Triton X-100, $0.5 \%$ sodium deoxycholate, $0.1 \%$ sodium dodecyl sulfate, $2 \mathrm{mM}$ EDTA) containing protease inhibitor cocktail (1:100, Sigma; St. Louis, MO, USA). Lysates were centrifuged at $4^{\circ} \mathrm{C}(10 \mathrm{~min}, 16,000 \times g)$, pellets were discarded, and the supernatants were aliquoted and stored at $-20^{\circ} \mathrm{C}$ for further analysis. Protein samples were subjected to 10\% SDS-polyacrylamide gel electrophoresis as described earlier [29]. The blots were incubated overnight at $4{ }^{\circ} \mathrm{C}$ with anti-phospho antibodies including: rabbit anti- 
p-Akt (Ser473; Cell Signaling, Danvers, MA, USA), rabbit anti-p-STAT3 (Tyr705; Abcam, Cambridge, UK), rabbit anti-p-STAT3 (Ser727; Cell Signaling), rabbit anti-p-STAT5 (Tyr694; Cell Signaling), as well as mouse anti-total STAT3 protein (Cell Signaling). Horseradish peroxidase (HRP)conjugated secondary goat anti-rabbit or anti-mouse antibodies (Jackson ImmunoResearch Laboratories, Inc., West Grove, PA, USA) were applied for $2 \mathrm{~h}$ at room temperature and the blots visualized using the enhanced chemiluminescence detection kit (EZ-ECL, Biological Industries, Kibbutz Beit Haemek, Israel). The blots were scanned and quantified with NIH Image 1.63. Levels of $\beta$-actin and the total STAT3 proteins were used as loading controls and for further data normalization.

We would like to note that $8 \mathrm{~h}$ MOG35-55 stimulation resulted in a lower yield of encephalitogenic T cells following the use of the CD4 microbead system. We assume that this change in CD4 yield reflects transient downregulation (internalization and turnover) in CD4 receptor expression following antigen stimulation [35,36]. Indeed, immunoblotting of STAT3 and $\beta$-actin proteins confirmed a decrease in total level of both of these proteins by about 35\% in all MOG-treated samples. This observation corresponds well with these previous reports on post-stimulation CD4 receptor downregulation $[35,36]$. Addition of $5 \mu \mathrm{M}$ CBD had no further effect.

\section{RNA extraction, quantitative PCR (qPCR) and microarray transcript analysis}

The Miltenyi CD4 bead purified $\mathrm{T}_{\mathrm{MOG}}$ cells were lysed and subjected to RNA extraction (5Prime, Darmstadt, Germany) followed by qPCR analysis as reported earlier [9]. The cDNA of each specific gene was amplified using a pair of specific primers as detailed in Table 1. Quantification was performed by 'the comparative cycle of threshold method' using $\beta 2$-microglobulin ( $\beta 2 \mathrm{MG}$ ) gene product for normalization [30]. The qPCR runnings were repeated 3 to 4 times using mRNA preparations from independent experiments.

For microarray transcripts, 200 ng samples of total RNA were amplified, labeled and hybridized onto Illumina MouseRef-8 v 2.0 Expression Bead-Chip (Illumina Inc., San Diego, CA, USA), querying the expression of $>24,000$ RefSeq-curated gene targets and 796 random sequences (used for the assessment of background noise). Arrays were processed and scanned with Illumina BeadStation platform according to the manufacturer's protocol. Raw data were analyzed using the Bioconductor packages (http://www.bioconductor.org; [37]).

\section{Statistical analysis}

Data is expressed as the mean \pm SEM of two to four independent experiments and analyzed for statistical significance using one way analysis of variance (ANOVA), followed by Newman-Keul's or Dunnett's post hoc tests. $P<0.05$ was considered significant. Graph Pad Prism program (La Jolla, CA, USA) was used for statistical analysis of the data.

\section{Study approval}

All mice used in the studies were maintained according to the guidelines of the Institutional Animal Care and Use Committee (IACUC). Animal experiments were approved and performed by the Weizmann Institute of Science and the Tel Aviv University IACUCs.

\section{Results}

$\mathrm{CD} 4^{+} \mathrm{CD} 25^{+}$cell number is decreased by MOG35-55stimulation but not affected by CBD treatment

$\mathrm{T}_{\text {MOG }}$ cells were co-cultured with splenocytes (APC/ $\mathrm{T}_{\text {MOG }}$ co-cultures) and stimulated with MOG35-55 at $5 \mu \mathrm{g} / \mathrm{ml}$ for $18 \mathrm{~h}$ in the presence or absence of $5 \mu \mathrm{M}$ CBD, and the number of $\mathrm{CD}^{+}$cells was determined using flow cytometry. As presented in Figure 1A, neither MOG35-55stimulation nor CBD addition affected the total number of $\mathrm{CD}^{+}$cells in these co-cultures. Next, we analyzed the frequency of $\mathrm{CD} 4{ }^{+} \mathrm{CD} 25^{+}$natural regulatory $\mathrm{T}$ cells in $\mathrm{APC} /$ $\mathrm{T}_{\text {MOG }}$ co-cultures (Figure $1 \mathrm{~B}$ ). We observed that in control, non-stimulated co-cultures $11.0 \% \pm 1.4 \%$ of $\mathrm{CD}^{+}$cells were $\mathrm{CD} 25$ positive $\left(\mathrm{CD} 4{ }^{+} \mathrm{CD} 25^{+}\right)$and this frequency did not change following CBD treatment $(10.4 \% \pm 1.5 \%$; Figure 1 ,D). MOG35-55-stimulation of these APC/ $\mathrm{T}_{\text {MOG }}$ co-cultures led to a significant decrease in $\mathrm{CD} 4{ }^{+} \mathrm{CD} 25^{+}$ cells (down to $5.5 \% \pm 0.5 \%$ of all $\mathrm{CD}^{+}, P<0.05$ ), and this level was not affected by CBD co-incubation ( $5.6 \% \pm 0.3 \%)$.

\section{CBD induces upregulation of $\mathrm{CD} 4^{+} \mathrm{CD} 25^{-} \mathrm{CD} 69^{+} \mathrm{LAG}^{+}$}

cells in MOG35-55-stimulated APC/T $\mathrm{T}_{\text {MOG }}$ co-cultures

At the second step, we analyzed the $\mathrm{CD} 4^{+} \mathrm{CD} 25^{-}$population for the expression of CD69 molecule. In control, non-

Table $\mathbf{1}$ Primers used for qPCR analysis of $\mathbf{m R N A}$ levels in purified $\mathbf{T}_{\mathbf{M o g}}$ cells co-cultured previously with adherent
\begin{tabular}{llll} 
APCs & & Reverse \\
\hline Gene & Accession number & Forward & TCGGCCATACTGGCATGCTTAACT \\
\hline$\beta_{2}$ MG & NM_009735 & AGTTCCACCCGCCTCACATTGAAA & ACACCATAGTCAATAAGCCATC \\
STAT5 & NM_010118.3 & AGTTGTGGAGAGAGAAACAATC & CCATCTCCGTCTCCAGTT \\
LAG3 & NM_008479.2 & CTGCCTTAGAACATGGGATTC & ACACCATAGTCAATAAGCCATC \\
EGR2 & NM_010118.3 & AGT TGTGGAGAGAGAAACAATC & GGATCTCCCTGGTTCTCTT \\
IL-10 & NM_010548.2 & CCTTTGCTATGGTGTCCTTC &
\end{tabular}



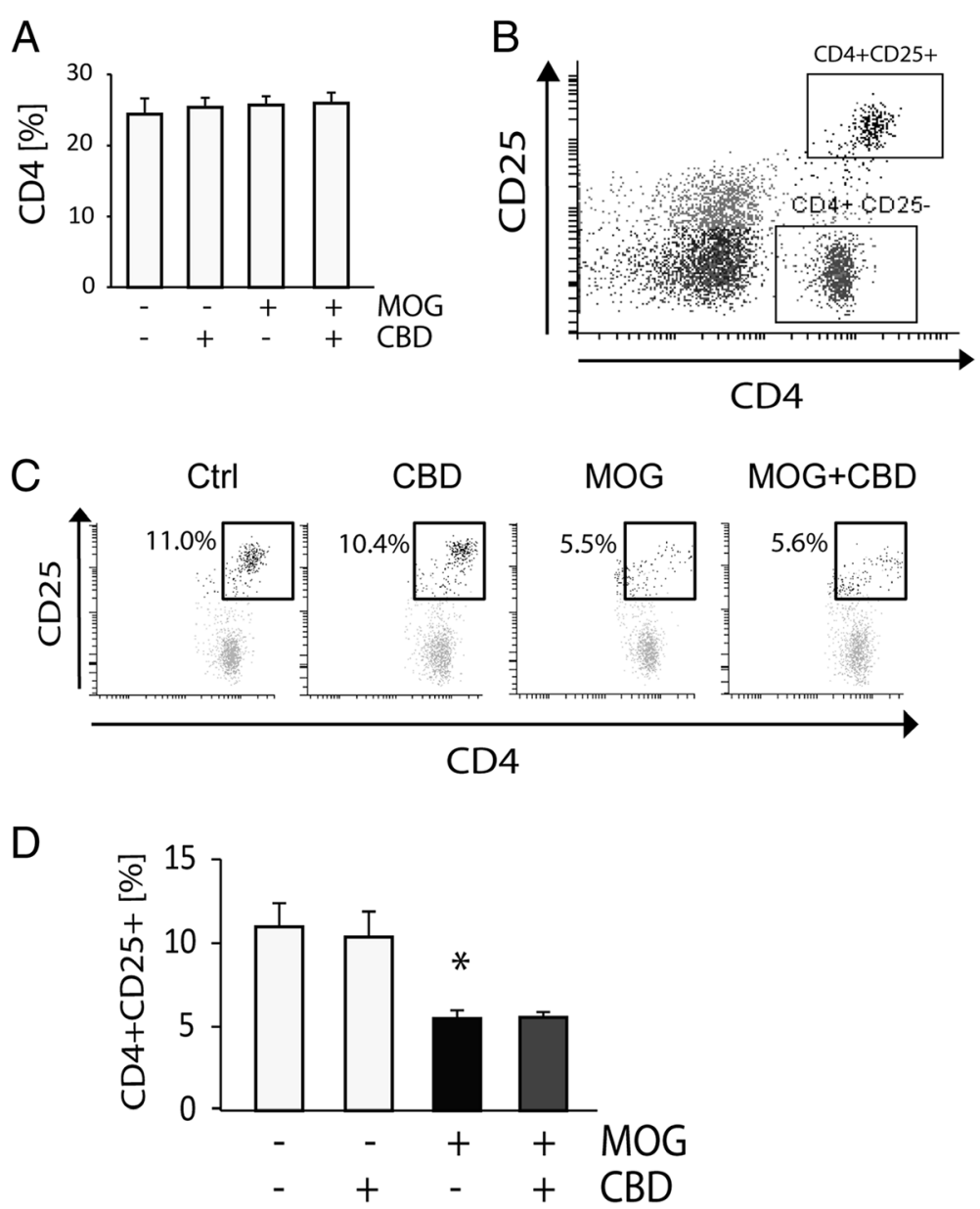

Figure 1 Decrease in $\mathrm{CD}^{+}{ }^{+} \mathrm{CD} 25^{+}$cells in MOG35-55-stimulated APC/T ${ }_{\text {MOG }}$ co-cultures is not affected by CBD. Splenocytes (including accessory $C D 4^{+} T$ cells) were co-cultured with $T_{\text {MOG }}$ cells and stimulated with MOG35-55 at $5 \mu \mathrm{g} / \mathrm{ml}$. CBD at $5 \mu$ M was added to the cells immediately before MOG35-55. (A) Bar graph showing the average percentage of CD4 $4^{+}$cells in APC/ $T_{\text {MOG }}$ Co-cultures $(100 \%$ as equal to total

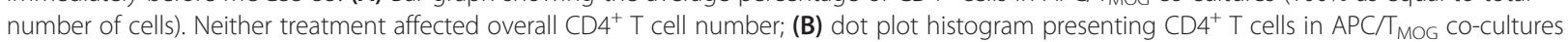
positive and negative for CD25 expression; (C) a representative dot plot showing the changes in $C D 4^{+} \mathrm{CD} 25^{+} \mathrm{T}$ cell population in control or

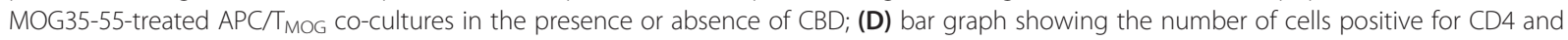
CD25 \pm SEM. ANOVA $F(3,8)=7.8, P<0.01 .{ }^{*} P<0.05$ vs non-stimulated cells. $n=3$ to 4 .

stimulated $\mathrm{APC} / \mathrm{T}_{\mathrm{MOG}}$ co-cultures $9.3 \% \pm 0.4 \%$ of the $\mathrm{CD} 4{ }^{+} \mathrm{CD} 25^{-}$cells were found to be positive for $\mathrm{CD} 69$ (Figure 2A). Interestingly, $18 \mathrm{~h}$ co-incubation with CBD resulted in a very significant increase in $\mathrm{CD} 4^{+} \mathrm{CD} 25^{-} \mathrm{CD} 69^{+}$ cells reaching $22.5 \% \pm 1.3 \%(P<0.001$ vs $9.3 \% \pm 0.4 \%$ observed in the non-stimulated $\mathrm{APC} / \mathrm{T}_{\mathrm{MOG}}$ co-cultures). MOG35-55-stimulation of APC/ $\mathrm{T}_{\mathrm{MOG}}$ co-cultures resulted in doubling the $\mathrm{CD} 69$ expression on $\mathrm{CD} 4^{+} \mathrm{CD} 25^{-}$cells up to $18.0 \% \pm 1.5 \% \quad(P<0.001$ vs non-stimulated cells), and CBD addition together with MOG35-55 further increased the frequency of $\mathrm{CD} 4^{+} \mathrm{CD} 25^{-} \mathrm{CD} 69^{+}$cells up to $36.6 \% \pm$ $1.9 \%(P<0.001$ vs MOG-treated cells $)$.

Following incubation with CBD, we observed increased expression of LAG3 regulatory molecule on $\mathrm{CD} 4^{+} \mathrm{CD} 25^{-} \mathrm{T}$ cells. The basal number of $\mathrm{CD} 4^{+} \mathrm{CD} 25^{-}$cells expressing LAG3 $(9.7 \% \pm 2.6 \%)$ was increased by approximately three times reaching $29.0 \% \pm 2.8 \%$ in the presence of $\mathrm{CBD}$ (Figure 2B). MOG35-55 stimulation did not significantly affect the number of $\mathrm{CD}^{+}{ }^{+} \mathrm{CD} 25^{-} \mathrm{LAG}^{+}$cells $(13.3 \% \pm 3.3 \%)$ as compared to non-stimulated $\mathrm{APC} / \mathrm{T}_{\mathrm{MOG}}$ co-cultures. Addition of CBD to MOG35-55-stimulated APC/ $\mathrm{T}_{\mathrm{MOG}}$ cocultures resulted in a similar level of increase in LAG3 as observed in non-stimulated cells (reaching $29.6 \% \pm 2.7 \%$ of the total $\mathrm{CD} 4^{+} \mathrm{CD} 25^{-}$cells; Figure $2 \mathrm{~B}$ ).

Co-expression of CD69 and LAG3 molecules on CD4 ${ }^{+}$ $\mathrm{CD} 25^{-} \mathrm{T}$ cells has been defining an inducible nonclassical regulatory $\mathrm{T}$ cell phenotype [25]. The number of $\mathrm{CD} 4{ }^{+} \mathrm{CD} 25^{-}$cells double positive for CD69 and LAG3 in control $\mathrm{APC} / \mathrm{T}_{\mathrm{MOG}}$ co-cultures was $1.1 \% \pm 0.9 \%$ of the total $\mathrm{CD} 4{ }^{+} \mathrm{CD} 25^{-}$cells and this frequency was not significantly affected in the presence of $\mathrm{CBD}(3.1 \% \pm 2.7 \%$; Figure $2 \mathrm{C}, \mathrm{D})$. MOG35-55 stimulation of $\mathrm{APC} / \mathrm{T}_{\mathrm{MOG}}$ co- 


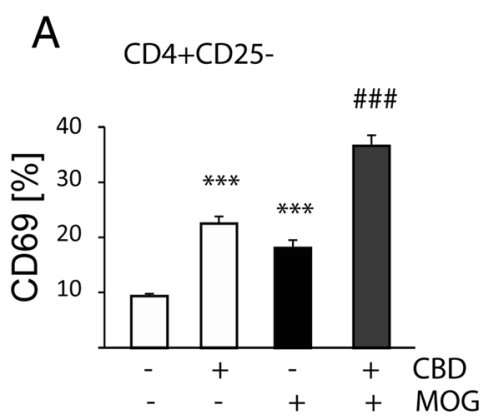

B

$\mathrm{CD} 4+\mathrm{CD} 25-$

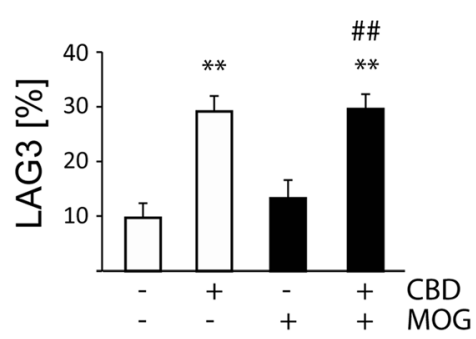

C $\mathrm{CD} 4+\mathrm{CD} 25-$
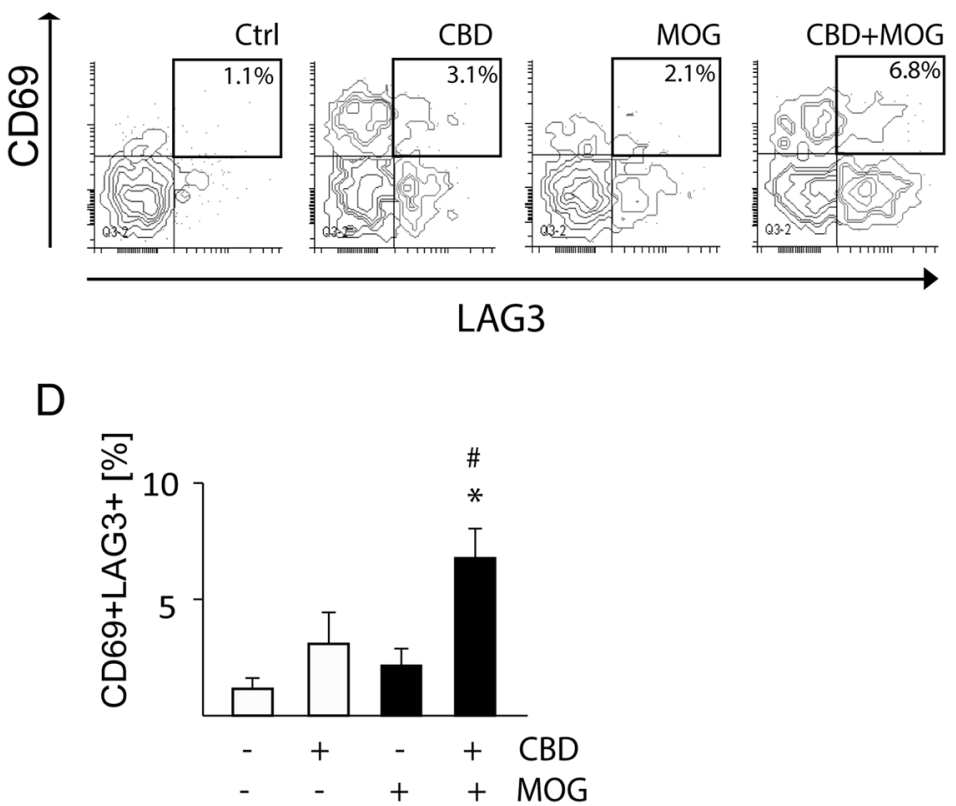

Figure 2 CBD treatment results in upregulation of $C D 69$ and of LAG3 regulatory molecules on $C D 4^{+} C D 25^{-}$T cells in MOG35-55stimulated $A P C / T_{M O G}$ co-cultures. APC/T MOG co-cultures were treated with MOG35-55 and CBD. (A) Percentage of CD4 $4^{+} C D 25^{-} \mathrm{T}_{\text {cells }}$ expressing CD69 (ANOVA $F(3,12)=68.9 ; P<0.001$ ); (B) percentage of $C D 4^{+} C D 25^{-}$T cells expressing LAG3 (ANOVA $\left.F(3,12)=13.0, P<0.001\right)$; (C) the representative contour plot density graphs showing the co-expression of $C D 69$ and LAG3 in the $C D 4^{+} C D 25^{-}$subpopulation; (D) percentage of $\mathrm{CD}^{+} \mathrm{CD} 25^{-}$cells expressing both CD69 and LAG3 \pm SEM. ANOVA $F(3,7)=7.3, P<0.05 .{ }^{*} P<0.05,{ }^{* *} P<0.01,{ }^{* * *} P<0.001$ vs non-stimulated cells; ${ }^{\#} P<0.05,{ }^{\# \#} P<0.01, \# \# P<0.001$ vs MOG35-55-stimulated cells. $n=3$ to 4.

cultures did not significantly affect the number of $\mathrm{CD} 4^{+}$ $\mathrm{CD} 25^{-} \mathrm{CD} 9^{+} \mathrm{LAG}^{+}$cells $(2.1 \% \pm 1.5 \%)$. However, CBD treatment led to a three-fold increase in $\mathrm{CD} 4^{+} \mathrm{CD} 25^{-}$ $\mathrm{CD} 9^{+} \mathrm{LAG}^{+}$cells, reaching $6.8 \% \pm 2.6 \%(P<0.05)$ in MOG35-55-treated cells (Figure 2C,D).

As controls, we analyzed the effects of CBD treatment on the expression of CD69 and of LAG3 on resting splenocytes cultured without $\mathrm{T}_{\text {MOG }}$ and without MOG35-55 as well as in resting $\mathrm{T}_{\mathrm{MOG}}$ cultured without MOG35-55 and without APC (both in maintenance medium). These control experiments showed that the levels of CD69 $(6.9 \% \pm$ $1.2 \%)$ and of LAG3 $(0.5 \% \pm 0.3 \%)$ in resting spleen-derived $\mathrm{CD}^{+}$splenocytes cultured separately were not significantly affected by CBD treatment (reaching $8.7 \% \pm 1.7 \%$ and $0.4 \% \pm 0.4 \%$, respectively; Table 2 ). Similarly, in resting
$\mathrm{T}_{\text {MOG }}$ cells cultured alone, CBD treatment did not affect the basal levels of CD69 $(0.9 \% \pm 0.3 \%$ in control cells and $1.0 \% \pm 0.2 \%$ in CBD-treated) and of LAG3 $(0.7 \% \pm 0.2 \%$ and $0.5 \% \pm 0.1 \%$, respectively). These experiments demonstrate that the changes in CD69 and LAG3 expression are induced by $\mathrm{CBD}$ treatment only in $\mathrm{APC} / \mathrm{T}_{\mathrm{MOG}}$ co-cultures and not in $\mathrm{T}_{\mathrm{MOG}}$ or in splenocytes cultured separately.

mRNA levels of anergy-associated genes are upregulated in MOG35-55-stimulated $\mathrm{T}_{\text {MOG }}$ cells and enhanced by CBD $\mathrm{CD}^{+}{ }^{+} \mathrm{CD} 25^{-} \mathrm{T}$ cells expressing CD69 and/or LAG3 have been shown to be potent inducers of anergy in activated effector/memory $\mathrm{T}$ cells via upregulating EGR2 transcription factor $[16,17]$. Thus, we examined the levels of EGR2 mRNA in non-stimulated and in MOG35-55- 
Table 2 CBD treatment does not affect CD69, CD25, and LAG3 expression in resting cells

\begin{tabular}{|c|c|c|c|}
\hline Phenotype & Control (\%) & CBD (\%) & $T$ test \\
\hline \multicolumn{4}{|c|}{ Resting splenocytes } \\
\hline $\mathrm{CD}^{+}$ & $20.0 \pm 2.7$ & $20.7 \pm 2.2$ & ns \\
\hline $\mathrm{CD}^{+} \mathrm{CD}^{+} 9^{+}$ & $6.9 \pm 1.2$ & $8.7 \pm 1.9$ & ns \\
\hline $\mathrm{CD}^{+} \mathrm{LAG}^{+}$ & $0.5 \pm 0.3$ & $0.4 \pm 0.4$ & ns \\
\hline $\mathrm{CD}_{19}{ }^{+}$ & $59.4 \pm 2.0$ & $59.4 \pm 2.1$ & ns \\
\hline $\mathrm{CD}_{19}{ }^{+} \mathrm{CD} 69^{+}$ & $13.6 \pm 3.4$ & $17.4 \pm 3.4$ & ns \\
\hline $\mathrm{CD}_{19}{ }^{+} \mathrm{CD} 25^{+}$ & $2.5 \pm 0.2$ & $3.1 \pm 0.2$ & ns \\
\hline \multicolumn{4}{|c|}{ Resting TMOG cells } \\
\hline $\mathrm{CD} 69^{+}$ & $0.9 \pm 0.3$ & $1.0 \pm 0.2$ & ns \\
\hline $\mathrm{LAG}^{+}$ & $0.7 \pm 0.2$ & $0.5 \pm 0.1$ & ns \\
\hline
\end{tabular}

Freshly isolated mouse splenocytes (including accessory $\mathrm{CD}^{+} \mathrm{T}$ cells and $\mathrm{CD}_{19^{+}} \mathrm{B}$ cells) or resting $\mathrm{T}_{\text {MOG }}$ cells were maintained separately for $18 \mathrm{~h}$ in maintenance medium without MOG35-55 and in the presence or absence of CBD at $5 \mu \mathrm{M}$. CD69, LAG3 and CD25 surface expression was analyzed using flow cytometry $(n=3)$. Data are expressed as percentage \pm SEM defined as the percent of cells expressing relevant antigen within an appropriate parent population.

ns, not significant

stimulated $\mathrm{T}_{\mathrm{MOG}}$ cells co-cultured with spleen-derived APC.

$\mathrm{T}_{\text {MOG }}$ cells were activated with MOG35-55 for $8 \mathrm{~h}$ in the presence of adherent APC. The floating $\mathrm{T}_{\mathrm{MOG}}$ cells were then collected and purified using CD4 microbeads and their mRNA subjected for qPCR analysis of EGR2 mRNA. We found that MOG35-55 stimulation dramatically upregulated the expression of EGR2 mRNA in the purified $\mathrm{T}_{\mathrm{MOG}}$ cells as compared to control cells $(P<0.01$; Figure $3 \mathrm{~A})$. This effect was potentiated by CBD treatment by another $25 \%(P<0.05)$. CBD itself slightly but insignificantly increased the expression of EGR2 mRNA in non-stimulated $\mathrm{T}_{\mathrm{MOG}}$ cells.

In parallel, we have evaluated the mRNA levels of other anergy promoters including STAT5 transcription factor, LAG3, and the IL-10 anti-inflammatory cytokine. Figure 3B shows that MOG35-55 stimulation increased STAT5 mRNA in $\mathrm{T}_{\text {MOG }}$ cells (by twofold; $P<0.05$ ). CBD did not have any further effect on MOG35-55-upregulated STAT5 mRNA expression. CBD did not affect the basal STAT5 levels either (Figure 3B). Interestingly, CBD significantly upregulated (by $c a$ fivefold) the level of LAG3 mRNA in control, non-stimulated $\mathrm{T}_{\mathrm{MOG}}$ cells previously co-cultured with adherent APC $(P<0.01$; Figure $3 C)$. Stimulation with MOG35-55 led to a very high LAG3 mRNA upregulation (by $c a$ tenfold, $P<0.001$ ). Moreover, the amount of LAG3 mRNA expression was further increased in the presence of CBD by additional $120 \%(P<0.001$; Figure $3 C)$. In the case of IL-10, neither CBD addition nor MOG35-55 stimulation affected the level of IL-10 mRNA expression (Figure 3D). However, CBD treatment of MOG35-55-stimulated cells resulted in a significant IL-10 mRNA upregulation of $100 \%$ above the level observed in MOG35-55-treated $\mathrm{T}_{\text {MOG }}$ cells $(P<0.01$; Figure 3D).

We performed gene array analysis of mRNA expression in $\mathrm{T}_{\mathrm{MOG}}$ cells in search for additional transcripts that are involved in anergy and tolerogenic processes. As shown in Table 3, MOG35-55-stimulation of $\mathrm{T}_{\mathrm{MOG}}$ cells led to a significant upregulation of various anergy promoters representing the following categories: regulators of cell cycle (Ndrg1 by 6.2-fold, Cdkn1a by 2.6-fold, Casp4 by 2.2-fold, and Fas by 2.6 -fold), tolerance inducers (Lag3 by 1.7 -fold, Icos by 1.6 -fold, Nfatc1 by 3.3 -fold), and chemokine recruiting regulatory $\mathrm{T}$ cells $(\mathrm{Ccl} 4$ by 9.1 -fold). The addition of CBD treatment significantly potentiated the MOG35-55upregulated transcript levels of tolerance inducers, that is, of Lag3 (by 305\%), Icos (by 43\%), and Nfatc1 (by 21\%) and of cell cycle regulators such as Cdkn1a (by 19\%), Casp4 (by 22\%), and Fas (by 27\%). It did not affect the MOG35-55enhanced levels of Ndrg1 and Ccl4. Treatment with CBD alone resulted in more than twofold increase of the levels of Icos, Ndrg1, and Casp4 in non-stimulated $\mathrm{T}_{\mathrm{MOG}}$ cells $(P<$ 0.005). Slight but significant increases were observed following CBD treatment for Lag3, Nfatc1, and Fas mRNA transcripts in non-stimulated $\mathrm{T}_{\mathrm{MOG}}$ cells.

\section{Th17 signature signaling pathways are affected by $C B D$ in} $\mathrm{T}_{\text {MOG }}$ cells co-cultured previously with APC

EGR2 was previously reported to control STAT3 and STAT5 activities, the main respective positive and negative regulators of Th17 phenotype [33]. Therefore, we evaluated the levels of STAT3 and STAT5 activation in $\mathrm{T}_{\mathrm{MOG}}$ cells. As described above, $\mathrm{T}_{\mathrm{MOG}}$ cells co-cultured with adherent spleen-derived APCs were stimulated with MOG35-55 in the presence or absence of $5 \mu \mathrm{M} \mathrm{CBD}$. After $8 \mathrm{~h}$ of stimulation, $\mathrm{CD} 4$ microbead purified $\mathrm{T}_{\mathrm{MOG}}$ cells were lysed, subjected to gel electrophoresis, and immunostained for phospho-STAT3 (at Tyr705 and Ser727) and for phosphoSTAT5 (at Tyr694).

A relatively high amount of STAT3 phosphorylated at Tyr705 (a major activating residue) as well as at Ser727 (enhancing STAT3 dimerization, translocation to the nucleus and DNA binding) was observed in $\mathrm{T}_{\mathrm{MOG}}$ cells even without stimulation with MOG35-55 (Figure 4A,B,E). MOG3555 stimulation led to a small, but significant, increase in the levels of phospho-STAT3 at both Tyr705 (by $20 \%, P<0.05$ ) and Ser727 (by $32 \%, P<0.001$ ). CBD treatment led to a large decrease in Tyr705 phosphoSTAT3 in both non-stimulated (reduction by $67 \%$ ) and stimulated $\mathrm{T}_{\mathrm{MOG}}$ cells (reduction by $68 \% ; P<0.001$ ). CBD decreased slightly, but significantly (by $15 \%$, $P<0.05)$, the phosphorylation of STAT3 at position Ser727 in non-stimulated $\mathrm{T}_{\mathrm{MOG}}$ cells and had a larger effect (decrease of $35 \%, P<0.001$ ) on Ser727 phosphorylation in the presence of MOG35-55 (Figure 4B,E). 

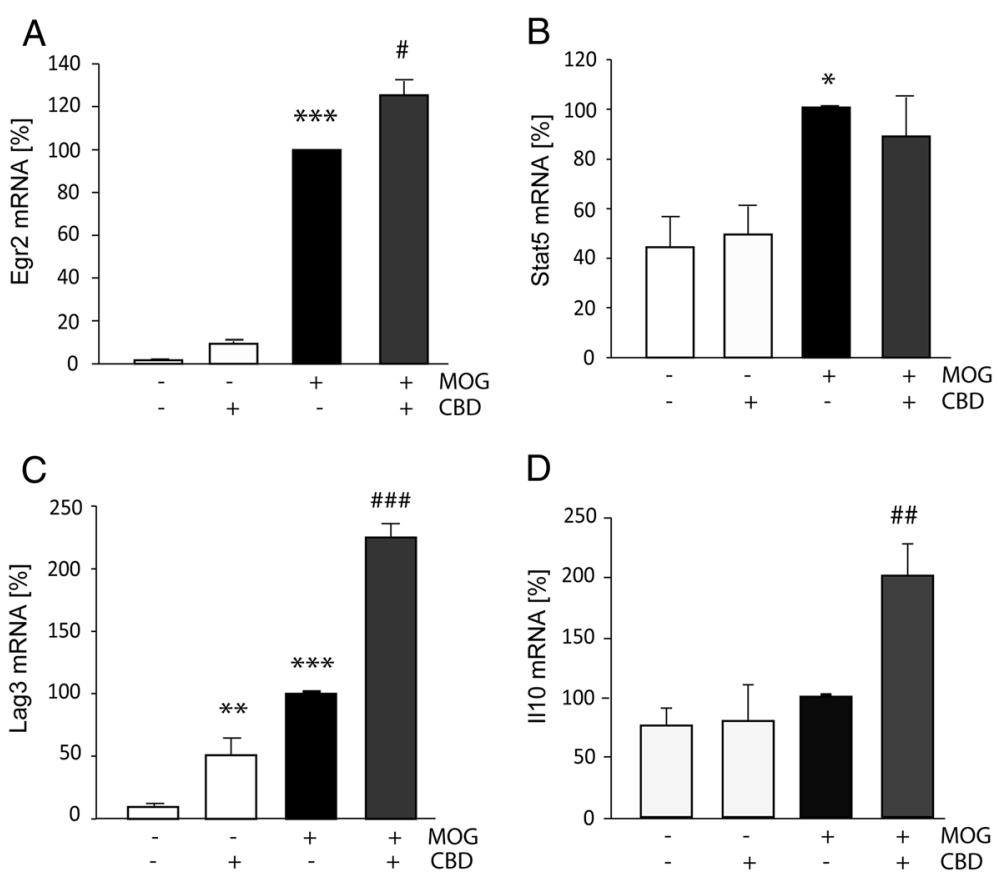

Figure 3 The effect of CBD treatment on EGR2, STAT5, LAG3, and IL-10 mRNA levels in purified TMOG previously co-cultured with APC. $\mathrm{T}_{\text {MOG }}$ cells were co-cultured with adherent APC and stimulated with MOG35-55 in the presence or absence of CBD. TMOG cells were then purified using $\mathrm{CD}^{+}$microbeads, lysed, and subjected for mRNA extraction and qPCR analysis using gene specific primers. The bar graphs show the levels of the indicated mRNAs as percentage of the amounts observed following stimulation with MOG35-55. (A) EGR2 mRNA (ANOVA F(3,4) =211.5, $P<0.001$ ); (B) STAT5 mRNA (ANOVA $F(3,12)=6.1, P<0.01$ ); (C) LAG3 mRNA (ANOVA $F(3,8)=116.5, P<0.001)$; (D) IL-10 mRNA (ANOVA $F(3,11)=9.9$,

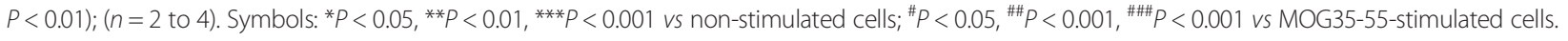

Interestingly, both CBD treatment and MOG35-55 stimulation increased STAT5 phosphorylation (at Tyr694). CBD addition to non-stimulated $\mathrm{T}_{\mathrm{MOG}}$ cells resulted in increased phospho-STAT5 levels (by $24 \%, P<0.05$ ), MOG3555 stimulation resulted in increased phospho-STAT5 levels of 30\% $(P<0.01)$. Applying MOG35-55 and CBD together resulted in an additive effect of $60 \%(P<0.01$, Figure 4D,E).

The Akt pathway is known to positively regulate effector T cells' proliferation while restraining intracellular regulatory mechanism [27]. Indeed, phospho-Akt levels were increased by $57 \%(P<0.001)$ in stimulated $\mathrm{T}_{\text {MOG }}$ cells co-cultured previously with APC. CBD treatment decreased Akt phosphorylation by $25 \% \quad(P<0.001$; Figure 4C,E). Moreover, CBD treatment also decreased phospho-Akt levels in non-stimulated $\mathrm{T}_{\mathrm{MOG}}$ cells by 20\% $(P<0.05)$.

We performed control experiments to evaluate if CBD treatment affects the activity of STAT3, STAT5,

Table 3 mRNA microarray analysis of CBD and MOG35-55 modulation of $\mathrm{T}_{\text {MOG }}$ cell activity

\begin{tabular}{|c|c|c|c|c|}
\hline Gene & Full name & MOG (fold change) & MOG + CBD (fold change) & CBD (fold change) \\
\hline Lag3 & Lymphocyte-activation gene 3 & 1.7 & 5.2 & 1.7 \\
\hline Icos & Inducible T-cell costimulator & 1.6 & 2.3 & 2.1 \\
\hline Nfatc1 & Nuclear factor of activated T-cells, cytoplasmic 1 & 3.3 & 4.0 & 1.3 \\
\hline Ndrg1 & N-myc downstream-regulated gene 1 & 6.2 & 6.7 & 2.5 \\
\hline Cdkn1a & Cyclin-dependent kinase inhibitor 1A & 2.6 & 3.1 & 1 \\
\hline Casp4 (Casp11) & Caspase 4, apoptosis-related cysteine peptidase & 2.2 & 2.7 & 2.1 \\
\hline Fas & Fas cell surface death receptor & 2.6 & 3.3 & 1.3 \\
\hline $\mathrm{Ccl} 4$ & Chemokine (C-C motif) ligand 4 & 9.1 & 9 & 0.9 \\
\hline
\end{tabular}

$\mathrm{T}_{\text {MOG}}$ /adherent APC co-cultures were stimulated with MOG35-55 in the presence or absence of CBD. mRNA from CD4 ${ }^{+}$microbead purified $\mathrm{T}_{\text {MOG }}$ cells was subjected to microarray analysis. The table presents the genes significantly upregulated by MOG35-55 and their modulation by CBD $(P<0.005)$. The data are expressed as fold change vs purified $\mathrm{T}_{\mathrm{MOG}}$ cells that were not stimulated by MOG35-55 when co-cultured with APC. Numbers in bold indicate significant effect of CBD vs the MOG35-55-induced effect. Values in italics indicate significant effects of CBD vs non-stimulated $\mathrm{T}_{\text {MOG }}$ cells $(P<0.005)$. 
A

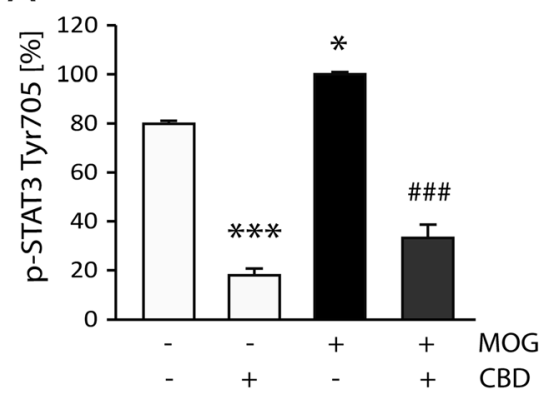

C
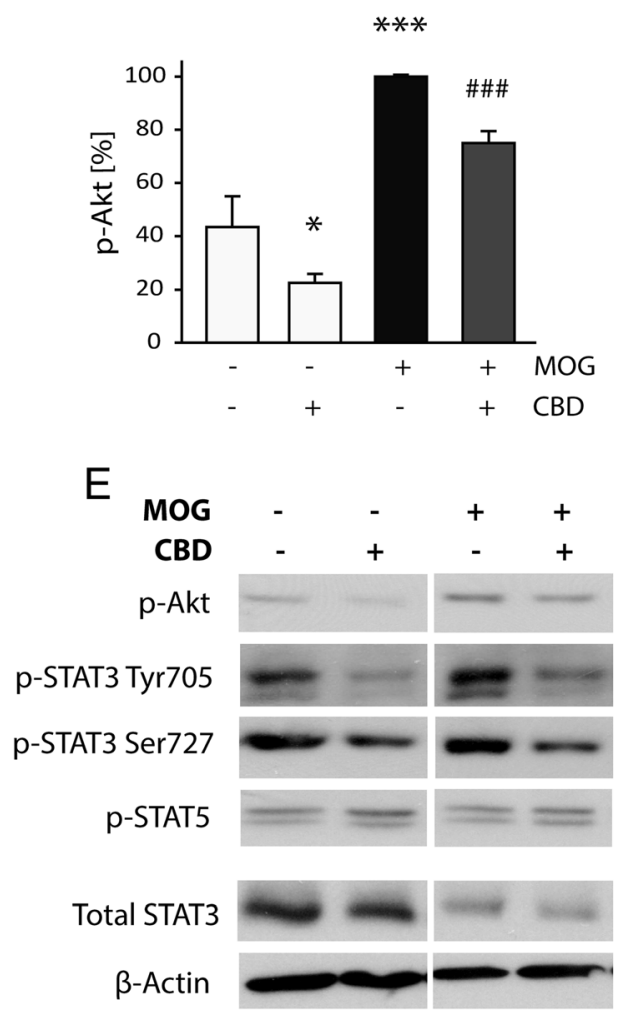

B

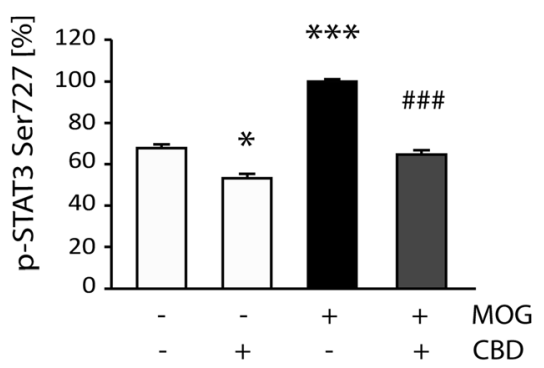

D

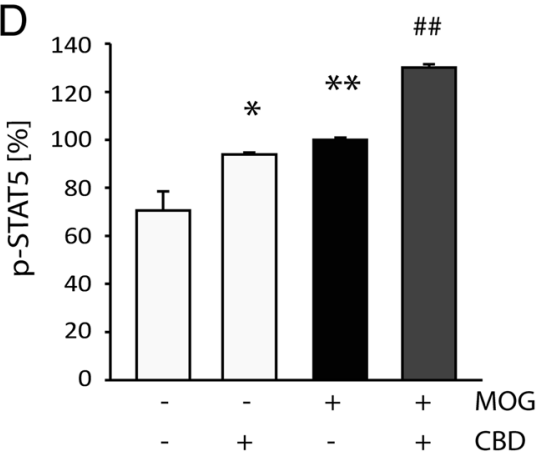

F

Resting TMOG

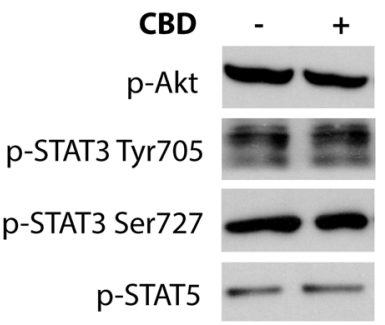

Figure 4 CBD modulates Th17 signaling pathways in $\mathrm{T}_{\text {MOG }}$ cells co-cultured with spleen-derived APC. Pre-adhered APC were co-cultured with $T_{\text {MOG }}$ cells and stimulated with MOG35-55 in the presence or absence of CBD. CD4 $4^{+}$microbead purified $T_{\text {MOG }}$ cells were lysed and proteins subjected to gel electrophoresis, followed by transfer to nitrocellulose membrane and immunostaining of the phosphorylated forms of Akt, STAT3, and STAT5 as well as of total amount of $\beta$-actin and STAT3. The bar graphs show average percentage values (in comparison to MOG35-55 without CBD as 100\%) of (A) phospho-STAT3 Tyr705 (ANOVA $F(3,4)=94.3, P<0.001$ ); (B) phospho-STAT3 Ser727 (ANOVA F $(3,4)=96.7, P<0.001$ ), (C) phospho-Akt (ANOVA $F(3,4)=96.7, P<0.001$ ); (D) phospho-STAT5 (ANOVA $F(3,7)=32.6, P<0.001$ ); (E) representative blots showing the phosphorylated forms of Akt, STAT3 (Tyr705 and Ser727), and STAT5 Tyr694 as well as total levels of $\beta$-actin and STAT3 ( $n=2$ to 3); (F) in this control experiment, resting $T_{M O G}$ cells were cultured without APC and without MOG35-55 for $8 \mathrm{~h}$ in the presence or absence of $5 \mu \mathrm{M} C B D$ in maintenance medium. Representative immunoblots $(n=2)$ show that CBD does not affect the levels of phospho-Akt, phospho-STAT3, and phospho-STAT5 in resting $\mathrm{T}_{\text {MOG }}$ cells cultured without APC. Symbols: ${ }^{*} P<0.05,{ }^{* *} P<0.01,{ }^{* * *} P<0.001$ vs non-stimulated purified $\mathrm{T}_{\text {MOGi }}{ }^{\# \#} P<0.001$, \#\#\# $P<0.001$ vs MOG35-55-treated $T_{\text {MOG }}$ cells.

and Akt pathways in resting $\mathrm{T}_{\mathrm{MOG}}$ cells cultured in maintenance medium without MOG35-55 stimulation and without splenocytes. Figure $4 \mathrm{~F}$ shows that CBD did not affect the phospho-STAT3 (Tyr705, Ser727), phospho-Akt, and phospho-STAT5 levels in these resting $\mathrm{T}_{\mathrm{MOG}}$ cells.
The expression of $\mathrm{MHCll}, \mathrm{CD} 25$, and $\mathrm{CD} 69$ on $\mathrm{CD}^{+} 9^{+} \mathrm{B}$ cells is downregulated following CBD treatment in MOG-stimulated APC/T ${ }_{\text {MOG }}$ co-cultures

LAG3 increases were found to reduce APC functions, including antigen presentation by MHCII molecules [12]. Indeed, MHCII expression is an important parameter in 
determining the antigen presenting efficiency of cells, including B cells, the main peripheral APC. We have, therefore, examined if the CBD-induced increase in LAG3 is accompanied by changes in $\mathrm{CD} 19^{+} \mathrm{B}$ cell APC activities. We found that neither MOG35-55 nor CBD treatments affected the total number of $\mathrm{CD} 19^{+} \mathrm{B}$ cells in $\mathrm{APC} / \mathrm{T}_{\text {MOG }}$ co-cultures (Figure 5A). CD19 $9^{\text {high }} \mathrm{B}$ cells were observed to be upregulated in autoimmune pathologies and proposed to be targeted in therapeutic approaches [38]. Indeed, we observed that $18 \mathrm{~h}$ MOG35-55 stimulation of $\mathrm{APC} / \mathrm{T}_{\mathrm{MOG}}$ co-cultures resulted in a significant increase in the number of $\mathrm{CD} 19^{\text {high }} \mathrm{MHCII}{ }^{\text {high }}$ cells $\left(35.5 \% \pm 5.0 \%\right.$ of all $\mathrm{CD} 19^{+}$ $\mathrm{MHCII}^{+}$cells), reaching almost twice the level observed in control, non-stimulated cells $(18.0 \% \pm 0.8 \%$; Figure $5 \mathrm{~B}$, C,D). Co-incubation of MOG35-55-stimulated APC/ $\mathrm{T}_{\text {MOG }}$ cells with $5 \mu \mathrm{M}$ of CBD resulted in a large decrease of $\mathrm{CD} 19^{\text {high }} \mathrm{MHCII}{ }^{\text {high }}$ cells back to the basal level of $22.0 \% \pm 2.0 \%(P<0.05)$. CBD did not affect the number of $\mathrm{CD} 19^{\text {high }} \mathrm{MHCII}^{\text {high }}$ cells in non-stimulated, control APC/ $\mathrm{T}_{\text {MOG }}$ co-cultures $(20.9 \% \pm 1.5 \%$; Figure $5 \mathrm{D})$.

CD25 antigen (that is, IL2 receptor $\alpha$ ) is recognized as a marker of $\mathrm{CD} 19^{+} \mathrm{B}$ cells autoimmune activity and is involved in cytokine secretion [39]. We observed that the frequency of $\mathrm{CD} 19^{+} \mathrm{CD} 25^{+}$cells was as low as $2.5 \%$ $\pm 0.2 \%$ of the total $\mathrm{CD} 19^{+} \mathrm{B}$ cell population in resting naïve spleen-derived APC cells cultured without encephalitogenic $\mathrm{T}_{\text {MOG }}$ (Table 2). However, the $\mathrm{CD} 19^{+} \mathrm{CD} 25^{+}$ frequency increased to $34.3 \% \pm 7.2 \%$ following coculturing of splenocytes with $\mathrm{T}_{\mathrm{MOG}}$ cells (Figure 6B,C). $\mathrm{CBD}$ did not affect the number of $\mathrm{CD} 19^{+} \mathrm{CD} 25^{+}$cells in non-stimulated $\mathrm{APC} / \mathrm{T}_{\mathrm{MOG}}$ co-cultures $(30.2 \% \pm 5.1 \%)$. On the other hand, MOG35-55 stimulation of APC/ $\mathrm{T}_{\text {MOG }}$ co-cultures resulted in a significant increase in $\mathrm{CD} 19^{+} \mathrm{CD} 25^{+}$cells (up to $54.8 \% \pm 2.4 \%$ of the total $\mathrm{CD} 19^{+}$cells, $P<0.01$ ), and this number was decreased in the presence of $\mathrm{CBD}$ to $41.6 \% \pm 2.5 \% \quad(P<0.05$ vs MOG35-55-stimulated cells) (Figure 6B,C).

CD69 level on $\mathrm{CD} 19^{+} \mathrm{B}$ cells serves as an indication of $B$ cells pro-inflammatory activity. In spleen-derived APC cultured without $\mathrm{T}_{\mathrm{MOG}}$ cells (resting splenocytes), $13.6 \% \pm 3.4 \%$ of the $\mathrm{CD} 19^{+} \mathrm{B}$ cells are CD69 positive and this expression is not significantly affected by CBD treatment $(17.4 \% \pm 3.4 \%$; Table 2$)$. However, co-culturing of spleen-derived APC cells with $\mathrm{T}_{\text {MOG }}$ cells resulted in a remarkable increase in CD69 antigen, particularly on $\mathrm{CD} 19^{\text {high }} \mathrm{B}$ cells as this population reached $44.2 \% \pm 2.6 \%$ of all $\mathrm{CD}_{19}{ }^{+} \mathrm{CD}_{69}{ }^{+}$cells (Figure $7 \mathrm{~B}, \mathrm{C}$ ). CBD coincubation decreased the number of $\mathrm{CD} 19^{\text {high }} \mathrm{CD} 69^{\text {high }}$ in non-stimulated $\mathrm{APC} / \mathrm{T}_{\mathrm{MOG}}$ co-cultures down to $21.6 \% \pm 5.9 \%(P<0.01)$. MOG35-55 stimulation of APC/ $\mathrm{T}$ co-cultures resulted in a further significant increase in $\mathrm{CD} 19^{\text {high }} \mathrm{CD} 69^{\text {high }}$ frequency reaching $70.0 \% \pm 1.0 \%$ of the total number of $\mathrm{CD} 19^{+}$cells $(P<0.01)$. This increase was reduced in the presence of CBD to $45.2 \% \pm 6.9 \%$ - a
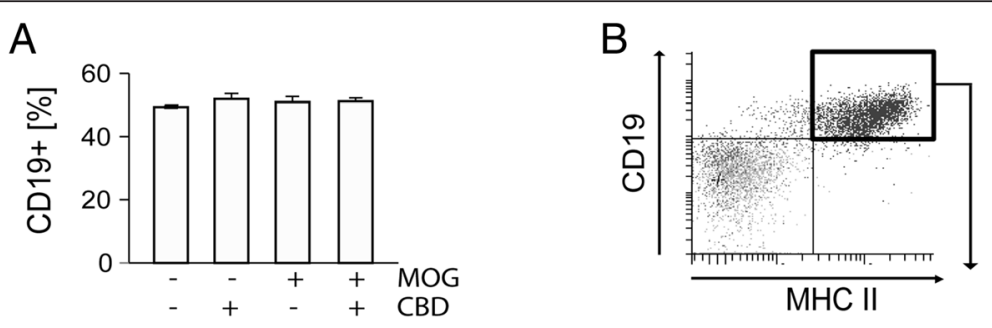

C

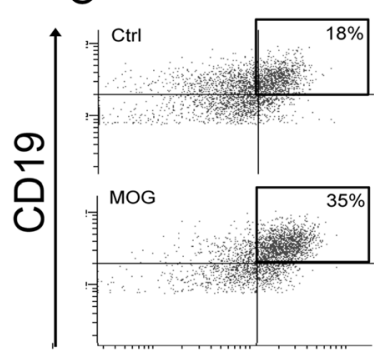

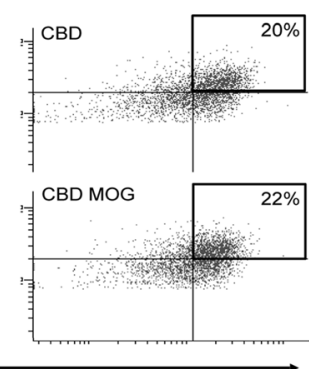

$\mathrm{MHC} \mathrm{II}$
D

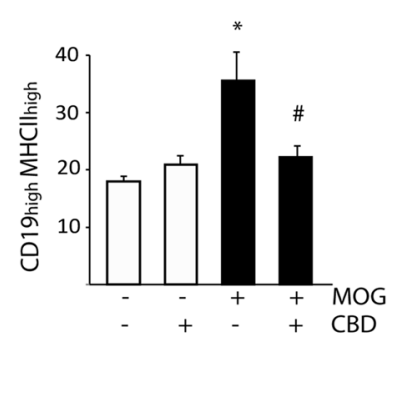

Figure 5 Upregulation of MHCII in CD19 ${ }^{\text {high }} \mathrm{B}$ cells in MOG35-55-stimulated APC/T MOG co-cultures is decreased by $C B D$. APC/T MOG co-cultures were stimulated with MOG35-55, treated with CBD and the percentage of CD19 ${ }^{\text {high }} \mathrm{MHC} \|^{\text {high }} \mathrm{B}$ cells determined using flow cytometry. (A) Neither treatment affected the number of CD19+ B cells; (B) dot plot showing representative flow cytometry gating of CD19+ $\mathrm{B}$ cells expressing MHCll; (C) representative dot plot graph of CD19 ${ }^{\text {high }} \mathrm{MHCl}^{\text {high }}$ cells; (D) bar graph showing the mean \pm SEM percentage of $\mathrm{CD} 19^{\text {high }} \mathrm{MHCl}^{\text {high }} \mathrm{B}$ cells within the total $\mathrm{CD} 19^{+} \mathrm{MHCII}^{+}$cells (taken as 100\%). ANOVA $F(3,8)=7.6, P<0.05 .{ }^{*} P<0.01$ vs control, ${ }^{\#} P<0.01$ vs MOG-stimulated cells. $n=3$. 

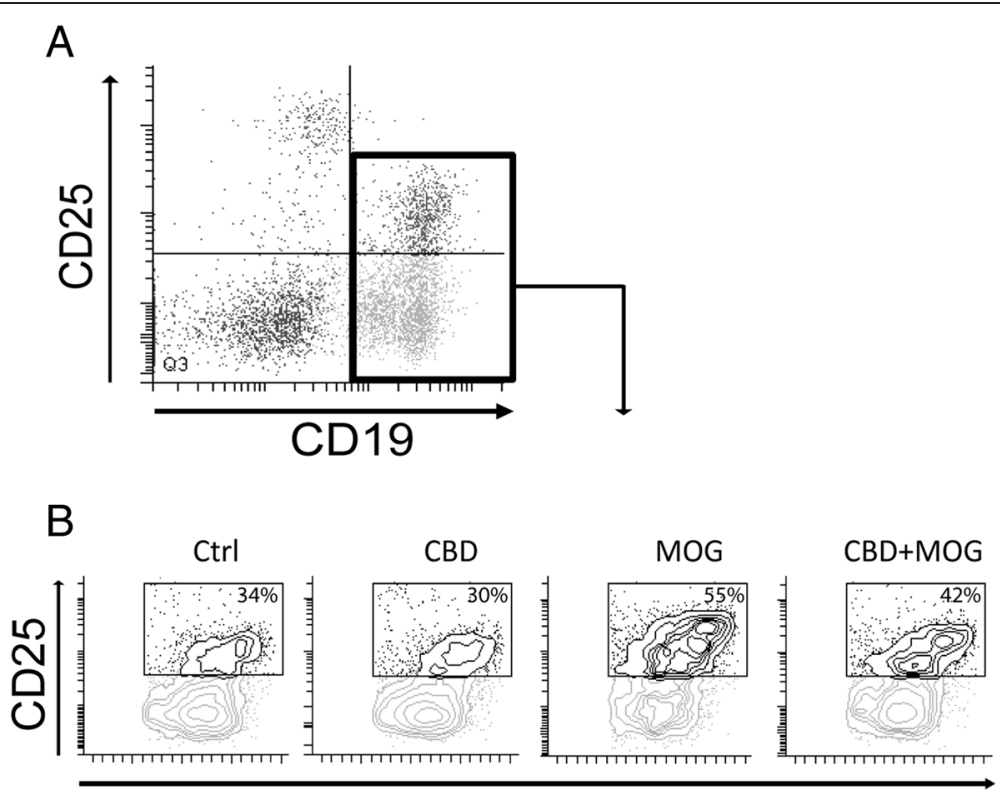

FSC

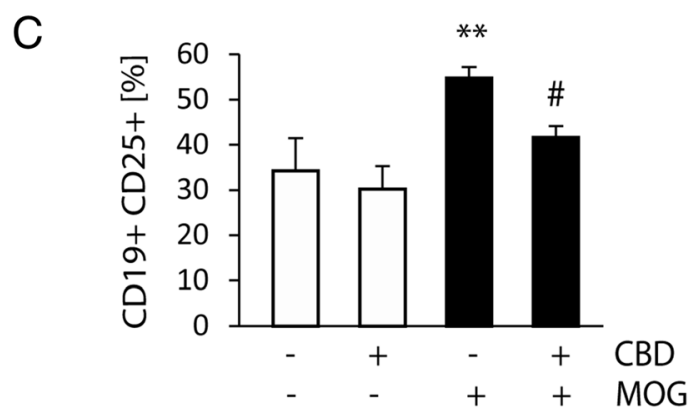

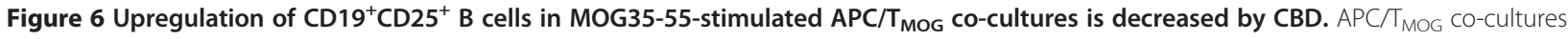
were treated as described above and cells were stained and analyzed by flow cytometry. (A) Dot plot showing gating for $C D 19^{+} \mathrm{CD} 25^{+}$cells; (B) density gradient graphs for CD25 expression on CD19+ cells; (C) bar graph showing the mean percent \pm SEM of CD19 ${ }^{+}$B cells expressing CD25. ANOVA $F(3,8)=8.8, P<0.01$ with $100 \%$ representing total $C D 19^{+}$cells. ${ }^{* *} P<0.01$ vs non-stimulated cells, ${ }^{*} P<0.01$ vs MOG35-55-stimulated cells. $n=3$.

reduction similar to that observed in non-stimulated $\mathrm{APC} / \mathrm{T}_{\mathrm{MOG}}$ co-cultures (Figure 7B,C).

\section{LAG3 expression on CD19 ${ }^{+} B$ cells is not affected by the presence of CBD}

Although LAG3 serves as a CD4 negative co-receptor and thus is mainly expressed on $\mathrm{CD}^{+} \mathrm{T}$ cells, its increased levels have been recently reported on $\mathrm{B}$ cells as well [40]. In our hands, the basal frequency of CD19 ${ }^{+}$ $\mathrm{LAG}^{+} \mathrm{B}$ cells in $\mathrm{APC} / \mathrm{T}_{\mathrm{MOG}}$ co-cultures was only $6.9 \% \pm 0.4 \%$ and was not affected by the presence of CBD (7.9\% \pm 0.9\%; Table 4). Moreover, neither MOG3555 stimulation nor MOG + CBD combination had any effect on $\mathrm{CD}_{19}{ }^{+} \mathrm{LAG}^{+}$cell frequencies in our APC/ $\mathrm{T}_{\text {MOG }}$ co-cultures $(6.0 \% \pm 0.4 \%$ and $5.7 \% \pm 0.9 \%$, respectively). Thus, in contrary to the situation in T cells,
LAG3 expression in B cells is not regulated by either MOG35-55 stimulation or CBD treatment.

\section{Discussion}

In this work, we studied the immunoregulatory effects of $\mathrm{CBD}$ using an in vitro model of $\mathrm{T}_{\mathrm{MOG}}$ cells cocultured with spleen derived APCs and other accessory cells. We found that CBD exerts its immunoregulatory effects by a de novo induction of regulatory $\mathrm{CD} 44^{+} \mathrm{CD} 25^{-}$ T cells that express high levels of suppressive CD69 and LAG3 molecules. This induction was accompanied by an increase in EGR2 transcription, as well as EGR2 and IL-10-dependent anergy of stimulated memory $\mathrm{T}_{\text {MOG }}$ cells and in a shift in STAT3/STAT5 activation balance. Moreover, we observed decreased antigen presenting capabilities (indicated by lower MHCII expression) and 


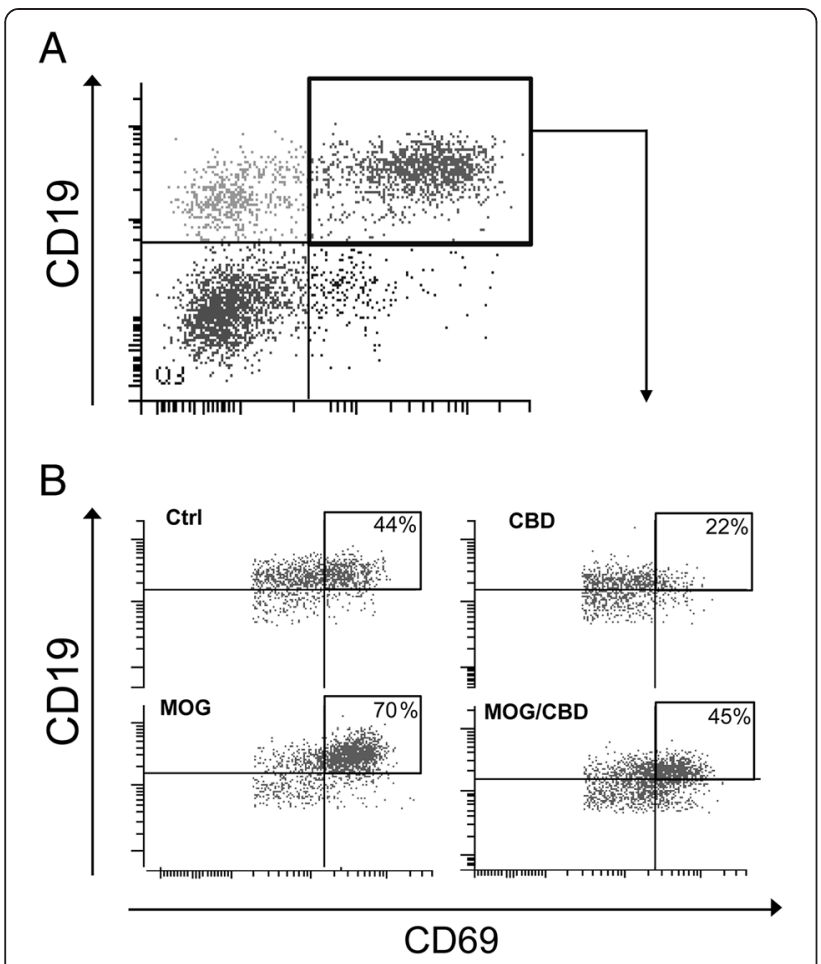

C

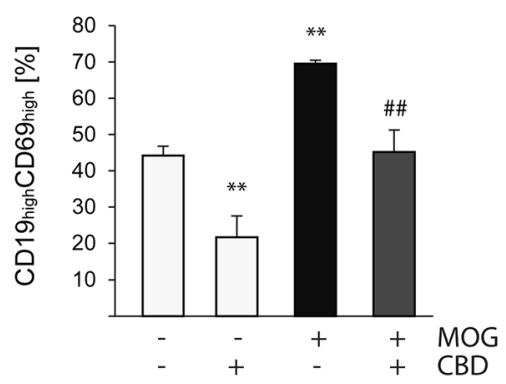

Figure 7 MOG35-55 increases and CBD decreases the number of $\mathrm{CD}_{19}{ }^{+} \mathrm{CD} 69^{+} \mathrm{B}$ cells in $\mathrm{APC} / \mathrm{T}_{\mathrm{MOG}}$ co-cultures. $\mathrm{APC} / \mathrm{T}_{\mathrm{MOG}}$ co-cultures were examined for $\mathrm{CD} 19^{+} \mathrm{CD} 69^{+}$cells using flow cytometry. (A) Dot plot graph showing gating for $\mathrm{CD} 19^{+} \mathrm{CD} 69^{+}$cells; (B) representative dot plots showing flow cytometry analysis of CD69 expression on $\mathrm{CD} 19^{+} \mathrm{B}$ cells with a quadrant marking CD19 ${ }^{\text {high }}$ CD69 $9^{\text {high }}$ cells; (C) bar graph showing the mean percentages \pm SEM of $\mathrm{CD} 19^{\text {high }} \mathrm{CD} 69^{\text {high }}$ within $\mathrm{CD} 19^{+} \mathrm{CD} 69^{+}$parent population (equivalent to 100\%). ANOVA $F(3,8)=19.3, P<0.001$. ${ }^{* *} P<0.01$ vs control, ${ }^{\#} P<0.01$ vs MOG-stimulated cells. $n=3$.

decreased pro-inflammatory activity (indicated by lower CD69 and CD25 expression) of MOG35-55-stimulated B cells in the presence of CBD (Scheme 1).

Naturally occurring $\mathrm{CD} 4^{+} \mathrm{CD} 25^{+}$regulatory $\mathrm{T}$ cells (nTreg) play an indispensable role in preventing autoimmunity mostly via Foxp3-dependent transcription [41]. Reduced frequency and reduced suppressive functions of nTreg (for example, via impaired STAT5 activity) have been observed in MS patients [42,43]. This phenomenon
Table 4 Level of LAG3 expression on CD19+ $B$ cells in the presence of CBD in APC/ MOG $_{\text {Co-cultures }}$

\begin{tabular}{ll}
\hline Treatment & CD19 $^{+}$LAG3 $^{+}$(\%) \\
\hline Control & $6.9 \pm 0.4$ \\
CBD & $7.9 \pm 0.9$ \\
MOG35-55 & $6.0 \pm 0.4$ \\
CBD + MOG35-55 & $5.7 \pm 0.9$ \\
\hline
\end{tabular}

$\mathrm{APC} / \mathrm{T}_{\text {MOG }}$ Co-cultures were stimulated with MOG35-55 and CBD. The level of LAG3 was measured by flow cytometry and is expressed as mean \pm SEM\% of CD $19^{+}$B cells positive for LAG3. ANOVA $F(3,8)=1.8, P>0.05(n=3)$.

was mimicked in our in vitro autoimmune model in which MOG35-55 stimulation resulted in reduced number of $\mathrm{CD} 4^{+} \mathrm{CD} 25^{+}$nTreg cells, demonstrating the suitability of this system for studying autoimmune inflammation and for identifying possible treatments. Interestingly, CBD did not reverse the MOG35-55-induced reduction in $\mathrm{CD}_{4}^{+}$ $\mathrm{CD}_{25}{ }^{+}$nTreg cells. Thus, we assume that other regulatory mechanisms mediate the anti-inflammatory activity of CBD in this system and in Th17-driven EAE.

Non-classical $\mathrm{CD}^{+} \mathrm{T}$ regulatory cells are induced in the periphery and have a pivotal role in maintaining immune tolerance, mainly via Foxp3-independent mechanisms. $\mathrm{CD} 4{ }^{+} \mathrm{CD} 25^{-} \mathrm{T}$ cells have been reported to be the main source of inducible regulatory phenotypes [23,24]. These cells exert their regulatory functions via a number of unique surface regulatory molecules, including LAG3 and CD69, acting separately or synergistically to diminish inflammation, including Th17-driven autoimmunity $[19,44]$. Such immunoregulation involves impaired antigen stimulation of $\mathrm{T}$ memory cells, impaired interactions of memory $\mathrm{T}$ cells with APC, promoting negative shift in Teff/Treg balance and/or inducing anergy in activated $\mathrm{T}$ cells. Our results show that CBD treatment upregulates the levels of CD69 as well as of LAG3 molecules on $\mathrm{CD} 4^{+} \mathrm{CD} 25^{-} \mathrm{T}$ cells (splenocytes) co-cultured with $\mathrm{T}_{\text {MOG }}$ cells. Moreover, in MOG35-55-stimulated APC/ $\mathrm{T}_{\mathrm{MOG}}$ co-cultures, CBD effect was augmented and led to the induction of regulatory phenotypes double positive for CD69 and LAG3, suggesting boosted immunoregulation upon self-antigen activation.

CD69 was shown to serve as a constitutive brake for Th17 differentiation $[18,19]$. CD69 has a negligible expression in resting $\mathrm{T}$ and $\mathrm{B}$ lymphocytes but is rapidly induced on these cells upon their activation [45]. CD69 was initially considered as an early activation marker and its key role in inducing regulatory mechanisms is well documented [18,46,47]. Although CD69 deficiency does not affect basal lymphocyte function, it leads to augmented autoimmunity including murine collageninduced arthritis, lupus, or autoimmune myocardiopathy ([48]; see [18] for additional refs). Indeed, CD69deficient naïve $\mathrm{T}$ cells preferentially differentiate toward 

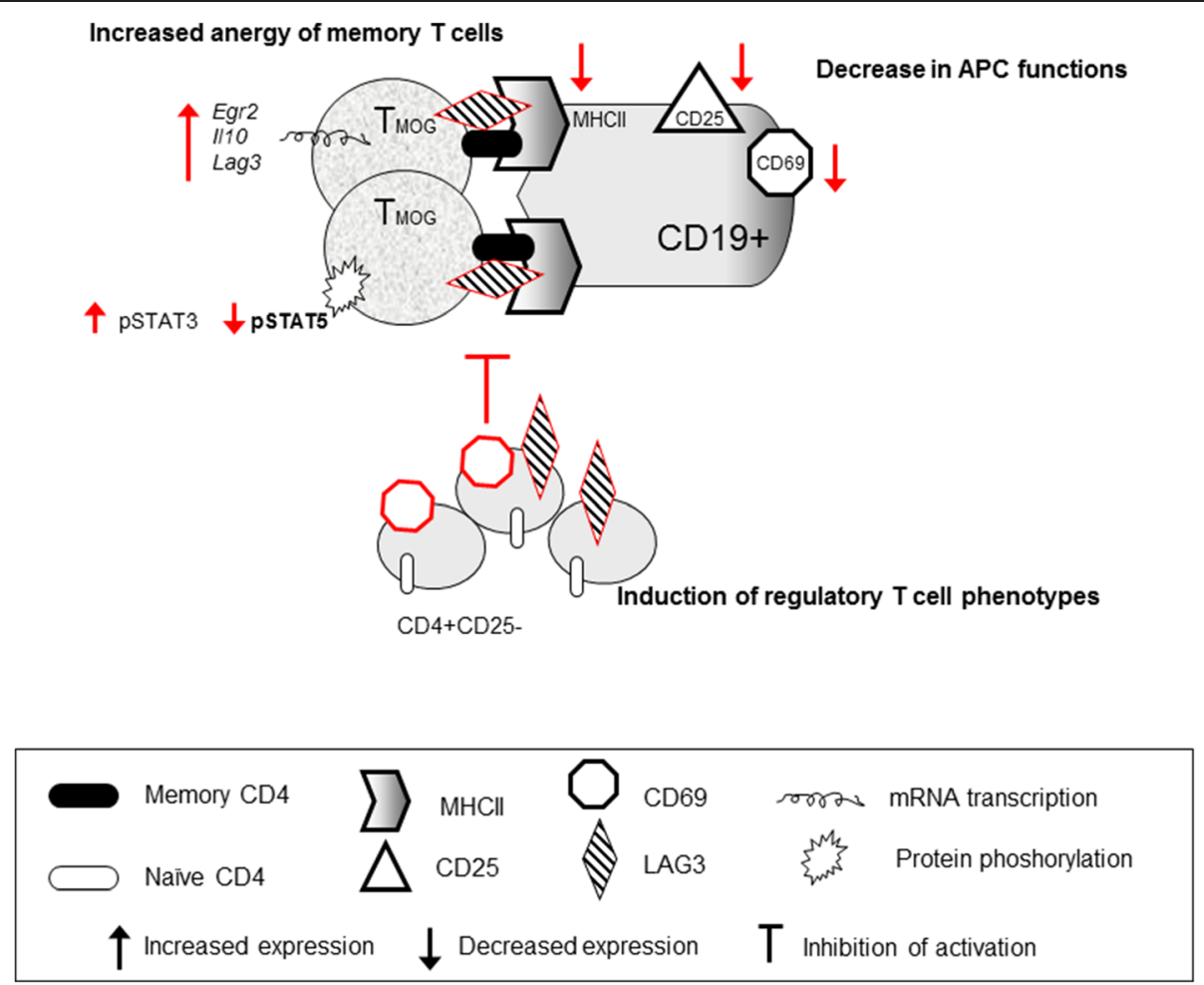

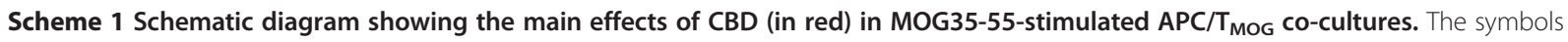
used in the scheme are explained below.

Th17, secrete high amounts of IL-17 following antigen stimulation in vitro and in vivo that is accompanied by increased STAT3/RORyt and diminished STAT5 activities [19]. In agreement with this, CD69 induction was shown to increase STAT5 suppressory activity and to decrease IL-17 release [19]. These observations are in line with our results showing that CBD upregulates CD69 on $\mathrm{CD} 4{ }^{+} \mathrm{CD} 25^{-} \mathrm{T}$ cells and that CBD treatment leads to decreased STAT3 and increased STAT5 phosphorylations in $\mathrm{T}_{\text {MOG }}$ cells.

LAG3 is similar to CD4 in its structure and genomic organization and serves as a high affinity, negative competitor of CD4 in binding MHCII [49,50]. LAG3 plays a crucial role in immune homeostasis involving antigen-stimulated $\mathrm{T}$ cells and has become a golden standard in tracking regulatory $\mathrm{T}$ cell phenotypes in many species, including human [44,51]. Interestingly, similarly to the case of CD69, LAG3 deficiency does not result in basal lymphocyte dysfunction but rather impairs tolerogenic mechanisms upon antigen activation leading to exacerbated autoimmunity. Basal levels of LAG3 in quiescent immune cells are low and this level is increased in activated $\mathrm{T}$ cells, including Th17 subtype, as a negative feedback loop response [20,49,50,52,53]. LAG3 was shown to reduce antigen-induced T cell expansion, to limit memory $\mathrm{T}$ cell pools [13], and to prevent various types of autoimmunity in mice [52,54-56]. LAG3 increased expression on regulatory cells has been accompanied by decreased IL-17 and increased IL-10 secretions [24,51,57]. Thus, the increase of LAG3 by CBD treatment reported here is in agreement with our previous results showing that CBD lowers IL-17 expression and secretion [9].

Increased LAG3 and IL-10 expressions are the most reliable markers of ongoing EGR2-driven anergic processes in activated T cells [24,25,57-59]. Forced expression of EGR2 in naïve $\mathrm{T}$ cells converts them into LAG3 expressing and IL-10 secreting regulatory cells [25] while EGR2 deficiency results in lupus-like autoimmunity [60], as well as increased STAT3 phosphorylation and IL-17 secretion [34]. Indeed, here we show that CBD treatment, that, as discussed above, decreases IL-17 secretion [9] promotes expression of EGR2 in $\mathrm{T}_{\text {MOG }}$ cells along with enhanced expression of LAG3 and IL-10 as well as of STAT5 phosphorylation.

Anergy-related decrease in T cell division and cytokine secretion (exhaustion) is driven by a well-defined set of tolerogenic genes and inhibitory proteins activated in response to antigen stimulation and is increased via EGR2 activation [16,61,62]. Accordingly, our gene transcript analysis of the effect of CBD on stimulated $\mathrm{T}_{\mathrm{MOG}}$ cells 
reveals enhanced anergy-related transcription profile. A number of transcripts are known to execute cell cycle arrest and EGR2-dependent tolerogenic events [16,62-64]. Several of these transcripts were found by us to be upregulated when CBD was added together with MOG35-55, including NFATc1, Casp4, Ndrg1, Lag3, and Icos. In addition, Akt activation, known for its role in restraining/ reversing anergy [27,65] was upregulated by MOG3555 -activation and reduced in the presence of CBD, adding to the anergy-facilitating environment induced by this cannabinoid.

MHCII-dependent APC function of B cells is required for the induction of MOG35-55-induced Th17 differentiation, memory $\mathrm{T}$ cells' expansion and EAE development [66]. B cells are the main source of IL-6 cytokine that controls Th17 differentiation [11]. Indeed, deficiency in IL-6-secreting B cells prevents IL-17 production and EAE [67]. This corresponds well with our recent observations that CBD decreases IL- 6 and IL-17 release from stimulated $\mathrm{T}_{\mathrm{MOG}}$ cells as well as lowers EAE severity $[8,9]$. Increased LAG3 was shown to impair antigen presenting functions of immune cells [68]. Thus, CBD-induced increase in LAG3 levels could lead to the reduced antigen presenting capacities in $\mathrm{B}$ cells as indeed indicated by lower MHCII levels in our system, along with the reduction in their pro-inflammatory activity as indicated by the lower levels of CD25 and CD69, molecules that serve as signature markers for B cell autoimmune activation $[39,69]$.

Interestingly, the CBD-induced shift in STAT3/STAT5 phosphorylation ratio, the decrease in Akt activity in $\mathrm{T}_{\text {MOG }}$ cells as well as the increases in CD69 and LAG3 expression on accessory $\mathrm{T}$ cells are also observed in $\mathrm{APC} / \mathrm{T}_{\mathrm{MOG}}$ co-cultures in the absence of MOG35-55 stimulation. This suggests that CBD may be raising an inherent basal activation threshold in these encephalitogenic T cells. Clearly, CBD-induced immunosuppression is amplified under activation conditions as evidenced by the induction of $\mathrm{CD}^{+} \mathrm{CD} 25^{-} \mathrm{CD} 69^{+} \mathrm{LAG}^{+}$cell population in CBD-treated MOG35-55-stimulated APC/ $\mathrm{T}_{\text {MOG }}$ co-cultures, accompanied by EGR2-dependent anergy in $\mathrm{T}_{\text {MOG }}$ cells co-treated with CBD and MOG35-55. Moreover, by changing the balance of STAT3/STAT5 transcription factors and by increasing IL-10 expression in stimulated $\mathrm{T}_{\text {MOG }}$ cells, CBD seems to turn pathogenic Th17 into non-pathogenic or even anti-inflammatory $\mathrm{T}$ cells. This phenomenon is known as a STAT5dependent cytokine switch of memory $\mathrm{T}$ cells and has a self-regulatory function [70,71]. It may involve inhibition of neighboring cells, such as APC [72].

\section{Conclusions}

Cannabinoid regulation of immune cell function was studied and reviewed by several other groups $[1,2,73,74]$.
Various cannabinoids have been shown to decrease maturation, proliferation, migration, adhesion, and cytokine secretion from activated immune cells. Our group and others identified MAPKs, AP-1, NFkB, STAT, and NFAT pathways as well as ROS formation to be targeted by cannabinoids in activated immune cells $[1,2,30,73,74]$. However, most of the data addressing these pathways was obtained with the use of naïve immune cells activated by non-specific activators, like phytohaemaglutinin, PMA/Ionomycin, and/or bacterial endotoxins, that only to a limited extent mimic the in vivo inflammation, particularly of autoimmune background. Moreover, although cell-mediated immunoregulation has been proved to be the most effective way of restoring immune homeostasis, the effect of cannabinoids on cell-mediated immunoregulation has been barely investigated so far. Recent work of Hegde et al. [75] showed that myeloidderived suppressor cells may mediate anti-inflammatory effects of CBD in autoimmune hepatitis suggesting that cannabinoids indeed have a potential to involve regulatory cells in their anti-inflammatory effects. Here, we are using an in vitro model, composed of memory $\mathrm{T}$ cells stimulated with myelin antigen in the presence of peripheral accessory cells to study the complex multicellular interactions driving the autoimmune inflammation and to study the effects of CBD on these processes. This approach mimics much better the in vivo autoimmune processes that take place in EAE mice. Our in vitro system allowed us to show that CBD anti-inflammatory activities in autoimmune conditions involve de novo induction of regulatory phenotypes, transcriptional and functional reprogramming of memory $\mathrm{T}$ cells toward non-pathogenic and even inhibitory cells (increased IL$10)$, as well as reduced activation of B cells, the main antigen presenting cells in the periphery.

\section{Abbreviations \\ APC: antigen presenting cells; CBD: cannabidiol; CD: cluster of differentiation; EAE: experimental autoimmune encephalomyelitis; EGR2: early growth response 2; LAG3: Iymphocyte-activation gene 3; MHCIl: major histocompatibility complex class II; MOG35-55: myelin oligodendrocyte glycoprotein 35 to 55; STAT: signal transducer and activator of transcription;

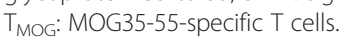

\section{Competing interests}

The authors declare that they have no competing interests.

\section{Authors' contributions}

EK, AJ, NK and ZV substantially contributed to discussions of article content and to reviewing and editing the manuscript before submission. $A B N$ and NK kindly provided the $T_{\text {MOG }}$ cells. NK and EK provided the know-how in $\mathrm{T}_{\text {MOG }}$ cell lines establishing and culturing. AJ performed the qPCR analysis of gene expression. GC carried out microarray experiments and analysis. EK designed and performed the experiments and wrote the article. All authors read and approved the final manuscript.

\section{Acknowledgements}

This work was supported by the Dr Miriam and Sheldon G. Adelson Medical Research Foundation. AJ is supported by the Israeli Ministry for Absorption in Science. 


\section{Author details}

${ }^{1}$ The Dr Miriam and Sheldon G. Adelson Center for the Biology of Addictive Diseases, Sackler Faculty of Medicine, Tel Aviv University, Tel Aviv, Israel. ${ }^{2}$ Neurobiology Department, Weizmann Institute of Science, Rehovot, Israel. ${ }^{3}$ Immunology Department, Weizmann Institute of Science, Rehovot, Israel. ${ }^{4}$ Neurology Department, UCLA, Los Angeles, CA, USA

\section{Received: 6 January 2015 Accepted: 26 February 2015} Published online: 15 March 2015

\section{References}

1. Klein TW. Cannabinoid-based drugs as anti-inflammatory therapeutics. Nat Rev Immunol. 2005;5(5):400-11.

2. Nagarkatti P, Pandey R, Rieder SA, Hegde VL, Nagarkatti M. Cannabinoids as novel anti-inflammatory drugs. Future Med Chem. 2009;1:1333-49.

3. Olsson T, Sun J, Hillert J, Höjeberg B, Ekre HP, Andersson G, et al. Increased numbers of $T$ cells recognizing multiple myelin basic protein epitopes in multiple sclerosis. Eur J Immunol. 1992;22(4):1083-7.

4. Wallström E, Khademi M, Andersson M, Weissert R, Linington C, Olsson T. Increased reactivity to myelin oligodendrocyte glycoprotein peptides and epitope mapping in HLA DR2(15) + multiple sclerosis. Eur J Immunol. 1998;28(10):3329-35.

5. Ben-Nun A, Cohen IR. Experimental autoimmune encephalomyelitis (EAE) mediated by $T$ cell lines: process of selection of lines and characterization of the cells. J Immunol. 1982;129:303-8.

6. Lyman WD, Sonett JR, Brosnan CF, Elkin R, Bornstein MB. Delta 9-tetrahydrocannabinol: a novel treatment for experimental autoimmune encephalomyelitis. J Neuroimmunol. 1989;23:73-81.

7. Maresz K, Pryce G, Ponomarev ED, Marsicano G, Croxford JL, Shriver LP, et al. Direct suppression of CNS autoimmune inflammation via the cannabinoid receptor CB1 on neurons and CB2 on autoreactive T cells. Nat Med. 2007;13:492-7

8. Kozela E, Lev N, Kaushansky N, Eilam R, Rimmerman N, Levy R, et al. Cannabidiol inhibits pathogenic $T$ cells, decreases spinal microglial activation and ameliorates multiple sclerosis-like disease in C57BL/6 mice. Br J Pharmacol. 2011;163:1507-19.

9. Kozela E, Juknat A, Kaushansky N, Rimmerman N, Ben-Nun A, Vogel Z. Cannabinoids decrease the th17 inflammatory autoimmune phenotype. J Neuroimmune Pharmacol. 2013;8(5):1265-76.

10. Harrington LE, Hatton RD, Mangan PR, Turner H, Murphy $T L$, Weaver $C T$. Interleukin 17-producing CD4+ effector Tcells develop via a lineage distinct from the T helper type 1 and 2 lineages. Nat Immunol. 2005;6:1123-32.

11. Zhou L, Ivanov II, Spolski R, Min R, Shenderov K, Egawa T, et al. IL-6 programs $T(H)-17$ cell differentiation by promoting sequential engagement of the IL-21 and IL-23 pathways. Nat Immunol. 2007:8:967-74.

12. Huard B, Prigent $P$, Pagès $F$, Bruniquel D, Triebel F. T cell major histocompatibility complex class II molecules down-regulate CD4+ T cell clone responses following LAG-3 binding. Eur J Immunol. 1996;26(5):1180-6.

13. Workman CJ, Vignali DA. The CD4-related molecule, LAG-3 (CD223), regulates the expansion of activated T cells. Eur J Immunol. 2003;33(4):970-9.

14. Sierro S, Romero P, Speiser DE. The CD4-like molecule LAG-3, biology and therapeutic applications. Expert Opin Ther Targets. 2011;15(1):91-101.

15. Chen L, Flies DB. Molecular mechanisms of T cell co-stimulation and co-inhibition. Nat Rev Immunol. 2013;13(4):227-42. doi:10.1038/nri3405.

16. Safford M, Collins S, Lutz MA, Allen A, Huang CT, Kowalski J, et al. Egr-2 and Egr-3 are negative regulators of T cell activation. Nat Immunol. 2005;6(5):472-80.

17. Anderson PO, Manzo BA, Sundstedt A, Minaee S, Symonds A, Khalid S, et al. Persistent antigenic stimulation alters the transcription program in T cells, resulting in antigen-specific tolerance. Eur J Immunol. 2006;36(6):1374-85.

18. Martín P, Sánchez-Madrid F. CD69: an unexpected regulator of TH17 cell-driven inflammatory responses. Sci Signal. 2011:4(165):e14.

19. Martín P, Gómez M, Lamana A, Cruz-Adalia A, Ramírez-Huesca M, Ursa MA, et al. CD69 association with Jak3/Stat5 proteins regulates Th17 cell differentiation. Mol Cell Biol. 2010;30(20):4877-89.

20. Workman CJ, Rice DS, Dugger KJ, Kurschner C, Vignali DA. Phenotypic analysis of the murine CD4-related glycoprotein, CD223 (LAG-3). Eur J Immunol. 2002:32(8):2255-63.

21. Han Y, Guo Q, Zhang M, Chen Z, Cao X. CD69+ CD4+ CD25- T cells, a new subset of regulatory $T$ cells, suppress $T$ cell proliferation through membrane-bound TGF-beta 1. J Immunol. 2009;182(1):111-20.
22. Ng WF, Duggan PJ, Ponchel F, Matarese G, Lombardi G, Edwards AD, et al. Human CD4(+)CD25(+) cells: a naturally occurring population of regulatory T cells. Blood. 2001;98(9):2736-44.

23. Feunou P, Poulin L, Habran C, Le Moine A, Goldman M, Braun MY. CD4 + CD25+ and CD4 + CD25- T cells act respectively as inducer and effector T suppressor cells in superantigen-induced tolerance. J Immunol. 2003;171(7):3475-84.

24. Fujio K, Okamura T, Yamamoto K. The Family of IL-10-secreting CD4+ T cells. Adv Immunol. 2010;105:99-130.

25. Okamura T, Fujio K, Shibuya M, Sumitomo S, Shoda H, Sakaguchi S, et al. CD4 + CD25-LAG3+ regulatory T cells controlled by the transcription factor Egr-2. Proc Natl Acad Sci U S A. 2009;106(33):13974-9.

26. Brownlie RJ, Zamoyska R. T cell receptor signalling networks: branched, diversified and bounded. Nat Rev Immunol. 2013;13(4):257-69.

27. Etemire E, Krull M, Hasenberg M, Reichardt P, Gunzer M. Transiently reduced PI3K/Akt activity drives the development of regulatory function in antigen-stimulated Naïve T-cells. PLoS One. 2013;8(7):e68378.

28. Dalton GD, Bass CE, Van Horn CG, Howlett AC. Signal transduction via cannabinoid receptors. CNS Neurol Disord Drug Targets. 2009;8(6):422-31.

29. Kozela E, Pietr M, Juknat A, Rimmerman N, Levy R, Vogel Z. Cannabinoids Delta (9)-tetrahydrocannabinol and cannabidiol differentially inhibit the lipopolysaccharide-activated NFkappaB and interferon-B/STAT cproinflammatory pathways in BV-2 microglial cells. J Biol Chem. 2010;285:1616-26.

30. Juknat A, Pietr M, Kozela E, Rimmerman N, Levy R, Gao F, et al. Microarray and pathway analysis reveal distinct mechanisms underlying cannabinoidmediated modulation of LPS-induced activation of BV-2 microglial cells. PLoS One. 2013;8:e61462

31. Harris TJ, Grosso JF, Yen HR, Xin H, Kortylewski M, Albesiano E, et al. Cutting edge: an in vivo requirement for STAT3 signaling in TH17 development and TH17-dependent autoimmunity. J Immunol. 2007;179(7):4313-7.

32. Laurence A, Tato CM, Davidson TS, Kanno Y, Chen Z, Yao Z, et al. Interleukin-2 signaling via STAT5 constrains T helper 17 cell generation. Immunity. 2007:26(3):371-81.

33. Yang XP, Ghoreschi K, Steward-Tharp SM, Rodriguez-Canales J, Zhu J, Grainger JR, et al. Opposing regulation of the locus encoding IL-17 through direct, reciprocal actions of STAT3 and STAT5. Nat Immunol. 2011:12(3):247-54

34. Miao T, Raymond M, Bhullar P, Ghaffari E, Symonds AL, Meier UC, et al. Early growth response gene-2 controls IL-17 expression and Th17 differentiation by negatively regulating Batf. J Immunol. 2013;190(1):58-65.

35. Rivas A, Takada S, Koide J, Sonderstrup-McDevitt G, Engleman EG. CD4 molecules are associated with the antigen receptor complex on activated but not resting T cells. J Immunol. 1988;140(9):2912-8.

36. Weyand CM, Goronzy J, Fathman CG. Modulation of CD4 by antigenic activation. J Immunol. 1987:138(5):1351-4.

37. Gentleman RC, Carey VJ, Bates DM, Bolstad B, Dettling M, Dudoit S, et al. Bioconductor: open software development for computational biology and bioinformatics. Genome Biol. 2004;5(10):R80.

38. Mei HE, Schmidt S, Dörner T. Rationale of anti-CD19 immunotherapy: an option to target autoreactive plasma cells in autoimmunity. Arthritis Res Ther. 2012;14(5):S1. doi:10.1186/ar3909.

39. Amu S, Strömberg K, Bokarewa M, Tarkowski A, Brisslert M. CD25-expressing B-lymphocytes in rheumatic diseases. Scand J Immunol. 2007;65(2):182-91.

40. Kisielow M, Kisielow J, Capoferri-Sollami G, Karjalainen K. Expression of lymphocyte activation gene 3 (LAG-3) on B cells is induced by T cells. Eur J Immunol. 2005;35(7):2081-8.

41. Hori S, Haury M, Coutinho A, Demengeot J. Specificity requirements for selection and effector functions of CD25 + 4+ regulatory T cells in anti-myelin basic protein T cell receptor transgenic mice. Proc Natl Acad Sci U S A. 2002;99(12):8213-8.

42. Viglietta $\mathrm{V}$, Baecher-Allan C, Weiner HL, Hafler DA. Loss of functional suppression by CD4 + CD25+ regulatory $T$ cells in patients with multiple sclerosis. J Exp Med. 2004;199(7):971-9.

43. Carbone F, De Rosa V, Carrieri PB, Montella S, Bruzzese D, Porcellini A, et al. Regulatory $T$ cell proliferative potential is impaired in human autoimmune disease. Nat Med. 2014;20(1):69-74.

44. Gagliani N, Magnani CF, Huber S, Gianolini ME, Pala M, Licona-Limon P, et al. Coexpression of CD49b and LAG-3 identifies human and mouse T regulatory type 1 cells. Nat Med. 2013;19(6):739-46.

45. Testi R, D'Ambrosio D, De Maria R, Santoni A. The CD69 receptor: a multipurpose cell-surface trigger for hematopoietic cells. Immunol Today. 1994;15(10):479-83. 
46. Sancho D, Gómez M, Viedma F, Esplugues E, Gordón-Alonso M, García-López MA, et al. CD69 downregulates autoimmune reactivity through active transforming growth factor-beta production in collagen-induced arthritis. J Clin Invest. 2003;112(6):872-82.

47. Sancho D, Gómez M, Sánchez-Madrid F. CD69 is an immunoregulatory molecule induced following activation. Trends Immunol. 2005;26(3):136-40.

48. Sancho D, Gómez M, Martinez Del Hoyo G, Lamana A, Esplugues E, Lauzurica P, et al. CD69 targeting differentially affects the course of collagen-induced arthritis. J Leukoc Biol. 2006;80(6):1233-41.

49. Bruniquel D, Borie N, Hannier S, Triebel F. Regulation of expression of the human lymphocyte activation gene-3 (LAG-3) molecule, a ligand for MHC class II. Immunogenetics. 1998;48(2):116-24.

50. Workman CJ, Vignali DA. Negative regulation of T cell homeostasis by lymphocyte activation gene-3 (CD223). J Immunol. 2005;174(2):688-95.

51. Roncarolo MG, Gregori S, Bacchetta R, Battaglia M. Tr1 cells and the counter-regulation of immunity: natural mechanisms and therapeutic applications. Curr Top Microbiol Immunol. 2014;380:39-68.

52. Bettini M, Szymczak-Workman AL, Forbes K, Castellaw AH, Selby M, Pan X, et al. Cutting edge: accelerated autoimmune diabetes in the absence of LAG-3. J Immunol. 2011;187(7):3493-8.

53. Lee $Y$, Awasthi A, Yosef N, Quintana FJ, Xiao S, Peters A, et al. Induction and molecular signature of pathogenic TH17 cells. Nat Immunol. 2012;13(10):991-9.

54. Okazaki T, Okazaki IM, Wang J, Sugiura D, Nakaki F, Yoshida T, et al. PD-1 and LAG-3 inhibitory co-receptors act synergistically to prevent autoimmunity in mice. J Exp Med. 2011;208(2):395-407.

55. Jha V, Workman CJ, McGaha TL, Li L, Vas J, Vignali DA, et al. Lymphocyte activation gene-3 (LAG-3) negatively regulates environmentally-induced autoimmunity. PLoS One. 2014;9(8):e104484

56. Nguyen TL, Makhlouf NT, Anthony BA, Teague RM, DiPaolo RJ. In vitro induced regulatory $T$ cells are unique from endogenous regulatory $T$ cells and effective at suppressing late stages of ongoing autoimmunity. PLoS One. 2014;9(8):e104698.

57. Bandukwala HS, Gagnon J, Togher S, Greenbaum JA, Lamperti ED, Parr NJ, et al. Selective inhibition of CD4+ T-cell cytokine production and autoimmunity by BET protein and c-Myc inhibitors. Proc Natl Acad Sci U S A. 2012;109 (36):14532-7.

58. Okamura T, Fujio K, Sumitomo S, Yamamoto K. Roles of LAG3 and EGR2 in regulatory T cells. Ann Rheum Dis. 2012;71 Suppl 2:i96-100.

59. Iwasaki Y, Fujio K, Okamura T, Yanai A, Sumitomo S, Shoda H, et al. Egr-2 transcription factor is required for Blimp-1-mediated IL-10 production in IL-27-stimulated CD4+ T cells. Eur J Immunol. 2013;43(4):1063-73.

60. Zhu B, Symonds AL, Martin JE, Kioussis D, Wraith DC, Li S, et al. Early growth response gene 2 (Egr-2) controls the self-tolerance of T cells and prevents the development of lupuslike autoimmune disease. J Exp Med. 2008;205(10):2295-307

61. Zheng Y, Zha Y, Driessens G, Locke F, Gajewski TF. Transcriptional regulator early growth response gene 2 (Egr2) is required for T cell anergy in vitro and in vivo. J Exp Med. 2012;209(12):2157-63.

62. Harris JE, Bishop KD, Phillips NE, Mordes JP, Greiner DL, Rossini AA, et al. Early growth response gene-2, a zinc-finger transcription factor, is required for full induction of clonal anergy in CD4+ T cells. J Immunol. 2004; 173(12):7331-8.

63. Schall TJ, O'Hehir RE, Goeddel DV, Lamb JR. Uncoupling of cytokine mRNA expression and protein secretion during the induction phase of $T$ cell anergy. J Immunol. 1992;148(2):381-7.

64. Ghosh S, Koralov SB, Stevanovic I, Sundrud MS, Sasaki Y, Rajewsky K, et al. Hyperactivation of nuclear factor of activated T cells 1 (NFAT1) in T cells attenuates severity of murine autoimmune encephalomyelitis. Proc Natl Acad Sci U S A. 2010;107(34):15169-74.

65. Gao B, Kong Q, Kemp K, Zhao YS, Fang D. Analysis of sirtuin 1 expression reveals a molecular explanation of IL-2-mediated reversal of T-cell tolerance. Proc Natl Acad Sci U S A. 2012;109(3):899-904.

66. Molnarfi N, Schulze-Topphoff U, Weber MS, Patarroyo JC, Prod'homme T, Varrin-Doyer M, et al. MHC class II-dependent B cell APC function is required for induction of CNS autoimmunity independent of myelin-specific antibodies. J Exp Med. 2013;210(13):2921-37.

67. Barr TA, Shen P, Brown S, Lampropoulou V, Roch T, Lawrie S, et al. B cell depletion therapy ameliorates autoimmune disease through ablation of IL-6-producing B cells. J Exp Med. 2012;209(5):1001-10.
68. Liang B, Workman C, Lee J, Chew C, Dale BM, Colonna L, et al. Regulatory T cells inhibit dendritic cells by lymphocyte activation gene-3 engagement of MHC class II. J Immunol. 2008;180(9):5916-26.

69. Vazquez BN, Laguna T, Carabana J, Krangel MS, Lauzurica P. CD69 gene is differentially regulated in $T$ and $B$ cells by evolutionarily conserved promoter-distal elements. J Immunol. 2009;183(10):6513-21.

70. Häringer B, Lozza L, Steckel B, Geginat J. Identification and characterization of IL-10/IFN-gamma-producing effector-like T cells with regulatory function in human blood. J Exp Med. 2009;206(5):1009-17.

71. Cope A, Le Friec G, Cardone J, Kemper C. The Th1 life cycle: molecular control of IFN- $\gamma$ to IL-10 switching. Trends Immunol. 2011;32(6):278-86.

72. Vendetti S, Chai JG, Dyson J, Simpson E, Lombardi G, Lechler R. Anergic T cells inhibit the antigen-presenting function of dendritic cells. J Immunol. 2000;165(3):1175-81.

73. Saito VM, Rezende RM, Teixeira AL. Cannabinoid modulation of neuroinflammatory disorders. Curr Neuropharmacol. 2012;10(2):159-66.

74. Fernández-Ruiz J, Sagredo O, Pazos MR, García C, Pertwee R, Mechoulam R, et al. Cannabidiol for neurodegenerative disorders: important new clinical applications for this phytocannabinoid? Br J Clin Pharmacol. 2013;75(2):323-33.

75. Hegde VL, Nagarkatti PS, Nagarkatti M. Role of myeloid-derived suppressor cells in amelioration of experimental autoimmune hepatitis following activation of TRPV1 receptors by cannabidiol. PLoS One. 2011;6(4):e18281. doi: 10.1371/journal.pone.0018281.

\section{Submit your next manuscript to BioMed Central and take full advantage of:}

- Convenient online submission

- Thorough peer review

- No space constraints or color figure charges

- Immediate publication on acceptance

- Inclusion in PubMed, CAS, Scopus and Google Scholar

- Research which is freely available for redistribution 